\title{
Evaluation of Spectral Interference of Lutetium on Analytes Including Specified Rare Earth Elements Using a CCD Detector-based ICP-AES
}

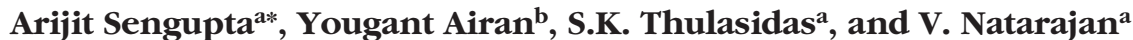 \\ ${ }^{a}$ Radiochemistry Division, Bhabha Atomic Research Centre, Trombay, Mumbai, India \\ ${ }^{b}$ Chemistry Department, Hindu College, University of Delhi, Delhi, India
}

\section{INTRODUCTION}

The radio-frequency-inductively coupled plasma (ICP) method has emerged as a very promising excitation source for atomic emission spectrometry (AES) with the advantages of good detection limits and high sensitivity with a large linear dynamic range (1-4). An ICP is a highly efficient atomization source, which means that every molecule should be dissociated provided that the operating conditions are optimized for this purpose. Many investigators have examined the analytical capabilities (5-7) of ICP sources for simultaneous multi-element optical emission analysis. In ICP-AES, the analytical response depends directly on the number of analyte atoms present in the plasma and, therefore, on the analyte concentration in the sample (8). However, ICP-AES suffers from some limitations which includes spectral interference due to spectrum richness, line broadening, and insufficient resolution from the matrices such as that of rare earth elements (REEs). Some kinds of interferences can be minimized or even eliminated by a judicious selection of the sample introduction system (9-10). Several authors have already indicated observable spectral interference either due to total or partial overlap of the lines (11-23) or to stray light (24-25). The major drawback of a photomultiplier tube (PMT) is that it is a single-channel detector which leads to a drastic waste of information, even when several detectors are set up in a polychromator. This

*Corresponding author.

E-mail: arijita@barc.gov.in

\begin{abstract}
The contribution due to the spectral interference of Lu in inductively coupled plasma atomic emission spectrometry was studied on 28 analytes including some rare earth elements (Gd, Dy, Nd, Ce, Pr, and La). Based on the analytical performance (including detection limit, sensitivity, linear dynamic range, and precision) and spectral interference contribution of $\mathrm{Lu}$, the best line(s) for the analytes were evaluated. The method was selected for the direct trace determination of the analytes in the presence of Lu without any chemical separation. An argon gas was used as the plasma source and a highly sensitive capacitatively coupled device (CCD) detector provided the selection of additional interference-free analytical lines of the elements. The method was validated using synthetic samples prepared from commercially available standard reference materials of the individual analytes and the correction factor was unified in the analysis.
\end{abstract}

drawback can be overcome by the use of multichannel detectors used with a commercially available ICPAES system such as those based on charge transfer technology.

2-D CCD or an association of linear CCD arrays has been used as the detector system with ICP-AES for the present investigation. Because it provides the advantages such as full flexibility in analytical line selection, use of several lines of the same element to extend the dynamic range, use of a large number of lines of the same element to improve accuracy and to verify possible matrix effects or spectral interferences, and qualitative analysis and fast diagnostic (26-29).

Lanthanides are found in nature in a number of minerals, but their separation process into individual metals is very complex. Lutetium can be used as catalyst in petroleum cracking in refineries, as organic synthesis, and as an internal standard in ICP-AES. Lutetium aluminum garnet has been proposed to be used as a lens material in immersion lithography (30) and in magnetic bubble memory devices (31). Lutetium also finds its application as detector in positron emission tomography (32) and as a phosphor in LED (33). The synthetic isotope lutetium-177 compounds are used in therapy for neuroendocrine tumors (34). For the above applications of Lu, especially in the medical field, there is a requirement of high purity Lu which leads to developing a methodology for the trace level determination of analytes in a Lu matrix.

Rare earth elements being multi-electronic systems exhibit line-rich emission spectra which can lead to spectral interference during the determination of elements in a rare earth matrix, mainly at trace levels. Therefore, in d.c. arc, the analytes are separated from the emission-rich matrix using a suitable carrier according to their volatilization properties (35-38), while ICP-AES involves chemical separation using suitable extractants (39-44). The poor analytical performance of the d.c. arc carrier distillation technique, including more sample handling in ICP-AES, neces- 
sitates a methodology for the direct determination of the analytes at trace levels in an emission-rich matrix without any separation. This requires a systematic study of the spectral interference of the emission-rich element on the analytes.

The present paper deals with the study of the spectral interference of Lu on different analytes (Ag, Al, B, $\mathrm{Ba}, \mathrm{Bi}, \mathrm{Cd}, \mathrm{Cr}, \mathrm{Cu}, \mathrm{Fe}, \mathrm{Ga}, \mathrm{Li}, \mathrm{Mg}$, Mn, Na, Ni, Sr, Zn, Ce, La, Gd, Nd, $\mathrm{Pr}, \mathrm{Dy}, \mathrm{Ca}, \mathrm{Co}, \mathrm{In}, \mathrm{Pb}$, and $\mathrm{Tl}$ ), involving identification of a suitable interference-free analytical tolerance level of Lu on the different analytical lines of these elements and evaluation of the correction factors for these lines. The analytical performance of these lines in a Lu matrix involving detection limits, sensitivity, precision, and linear dynamic range were studied systematically. Based on these factors, a method was developed for the direct determination of theses analytes at trace level in a Lu matrix without any separation steps. The method was validated with synthetic samples prepared from a standard reference material solution of the individual elements.

\section{EXPERIMENTAL}

\section{Instrumental and Operating Conditions}

The analysis was carried out using a Spectro-Arcos inductively coupled plasma atomic emission spectrometer (Spectro-Arcos, Germany), equipped with a capacitatively coupled device (CCD) detector. The operating conditions and instrumental specifications were optimized and are listed in Table I. The detector system, consisting of linear arrays of the CCD detector (3648 pixels/array), thermally stabilized together with an optical system, provides the ability to select alternate analytical lines. The cross-sectional view of the CCD-based detector system is shown elsewhere (26-28).

\section{Standard Solutions and Reagents}

Standard solutions for all of the elements were prepared from CertiPUR ${ }^{\circledR}$ ICP standard solutions (E-Merck, Darmstadt, Germany) by proper dilution. SupraPur ${ }^{\circledR} \mathrm{HNO}_{3}$ (E-Merck, Darmstadt, Germany) and quartz double distilled water were used throughout the study. Since the ICP-AES exhibits a high degree of linear dynamic range and in order to obtain more precise calibration curves, multi-point standardization was carried out using $0.5 \mathrm{M}$ $\mathrm{HNO}_{3}$ as a blank and $0.05-1000 \mathrm{mg} / \mathrm{L}$ of the corresponding elemental standard as the higher standards for each line after proper peak search. For the analysis of each sample, 10 replicate measurements were

\section{Atomic Apectroscopy \\ Vol. 36(2), March/April 2015}

carried out, while for the determination of the detection limits and the sensitivity, 25 replicate measurements were taken into account.

\section{Methods}

A series of Lu standard reference material (SRM) elemental solutions (E-Merck, Darmstadt, Germany) of concentrations between 0.05 to $1000 \mathrm{mg} / \mathrm{L}$ were prepared and fed into the atmospheric argon plasma. The spectral interference of Lu was monitored by observing the contribution in different channels of the specified analytes. For each analyte, the least interfered analytical lines were identified along with evaluation of the correction factor. The tolerance levels of Lu on these lines were also evaluated. The analytical

TABLE I

Specifications and Operating Conditions of ICP-AES

\begin{tabular}{ll}
\hline Instrumental Specifications & \\
\hline Optical design & Paschen-Runge mounting, Circular design \\
Focal length & $750 \mathrm{~mm}$ \\
Grating & Holographic \\
Groove density & 1800 grooves $/ \mathrm{mm}(1), 3600$ grooves/mm (2) \\
Wavelength range & $130-800 \mathrm{~nm}$ \\
Entrance slit width & 15 microns \\
Resolution (FWHM) & $0.01 \mathrm{~nm}$ from $130-450 \mathrm{~nm}$ \\
& $0.02 \mathrm{~nm}$ from $450-800 \mathrm{~nm}$ \\
Thermal regulation & Controlled to $30 \pm 1{ }^{\circ} \mathrm{C}$ \\
RF Frequency & $27.12 \mathrm{MHz}$ \\
Pump & Dual channel peristaltic pump \\
Detector & Linear arrays of CCD (3648 pixels/array) \\
Nebulizer & Pneumatic Concentric nebulizer with cyclonic \\
& spray chamber \\
ICP torch & Demountable, radial viewing \\
\hline Operating Conditions & \\
\hline Coolant flow & $15 \mathrm{~L} / \mathrm{min}$ \\
Auxiliary flow & $0.5 \mathrm{~L} / \mathrm{min}$ \\
Carrier gas flow & $1 \mathrm{~L} / \mathrm{mim}$ \\
Sample consumption rate & $1 \mathrm{~mL} / \mathrm{min}$ \\
Total time of measurement & $30 \mathrm{~s}$ \\
Pump speed & $30 \mathrm{Rpm}$ \\
Inp power output & $1.1 \mathrm{~kW}$ \\
\hline & $230 \mathrm{~V}$ AC \\
\hline
\end{tabular}


performance, including detection limits, sensitivity, and linear dynamic range, were studied for all of the analytical lines.

Since the correction factor is a function of the concentration of the interfering element, Lu, an ICPAES-based method was also developed for the simultaneous determination of Lu along with the analytes. The analytical performance, including detection limits, sensitivity, linear dynamic range, etc., were studied for all of the identified analytical lines of Lu.

Synthetic samples were used to validate the methodology of direct trace level determination of these analytes in the Lu matrix without any separation. The method was also compared with existing analytical techniques used for the trace level determination of these analytes. For common analytes (except for Ag), the d.c. arc carrier distillation technique was used, while for the rare earth elements, the ion chromatographic technique was used for comparison purposes. Ag was added to the samples in the form of $\mathrm{AgCl}$ for the d.c. arc carrier distillation technique. An independent analytical technique, i.e., atomic absorption spectrometry, was used to compare the results obtained by the newly developed ICP-AES method.

\section{RESULTS AND DISCUSSION}

\section{Determination of ICP-AES-based Methodology for Simultaneous Determination of $\mathrm{Lu}$}

Since the quantitative measure of spectral interference is a function of the concentration of interfering elements, it necessitates determining the interfering element with the highest merit of analytical performance, i.e., higher sensitivity, lower detection limit, higher precision, and larger linear dynamic range. In this study, an ICP-AESbased method was developed for the simultaneous determination of Lu along with all of the other analytes under investigation. Four different lines of Lu, e.g., $219.554 \mathrm{~nm}$, $261.542 \mathrm{~nm}, 291.139 \mathrm{~nm}$, and $307.760 \mathrm{~nm}$, were chosen. The emission profiles of the above-mentioned lines are shown in Figure 1, whereas the calibration curves using these lines are shown in Figure 2. From the calibration curve, the sensitivity of the above-mentioned lines was calculated and found to follow the trend: 261.542 $\mathrm{nm}>307.760 \mathrm{~nm}>291.139 \mathrm{~nm}>$ $219.554 \mathrm{~nm}$. The detection limit followed the trend: $261.542 \mathrm{~nm}<$ $291.139 \mathrm{~nm}-307.760 \mathrm{~nm}<$ $219.554 \mathrm{~nm}$. The linear dynamic range of these lines was also evaluated. Synthetic samples with various Lu concentrations ranging from 1 to $1000 \mathrm{mg} / \mathrm{L}$ were analyzed by this method. It was found that all of these lines can be used for the determination of Lu up to $1000 \mathrm{mg} / \mathrm{L}$ with an acceptable \%RSD (relative standard deviation). The analytical results for these synthetic samples and the analytical performance of these lines are summarized in Table II. Based on the above study, it is also clear that the Lu $261.542 \mathrm{~nm}$ line is the best line for its ICP-AES determination.

\section{Spectral Interference of $\mathrm{Lu}$ on} Ag, Al, B, Ba, Bi, Cd, Cu, Fe, Ga, Li, Mg, Mn, Na, Ni, Sr, Zn, and Cr

Four different analytical lines of $\mathrm{Ag}$ (338.289 nm, $328.068 \mathrm{~nm}$, $224.641 \mathrm{~nm}$, and $243.779 \mathrm{~nm}$ ) were chosen to study their analytical performance and the spectral interference of Lu. The study revealed that the Ag 338.289 $\mathrm{nm}$ and $328.068 \mathrm{~nm}$ lines were free of spectral interference, and the detection limit of the above lines follows the trend: $328.068 \mathrm{~nm}<338.289 \mathrm{~nm}<$ $243.779 \mathrm{~nm}<224.641 \mathrm{~nm}$. The sensitivity was found to follow the reverse trend of the detection limit. Other analytical performance figures of merit including \%RSD, lin- ear dynamic range, etc., indicated that the Ag $328.068 \mathrm{~nm}$ line was the best line for its determination in a Lu matrix. The detailed spectral interference of Lu revealed that the Al $396.152 \mathrm{~nm}, \mathrm{Al} 394.401 \mathrm{~nm}$, Al $309.271 \mathrm{~nm}$, B $249.677 \mathrm{~nm}$, B $208.959 \mathrm{~nm}, \mathrm{Ba} 455.404 \mathrm{~nm}$, Bi $306.772 \mathrm{~nm}$, Cd 214.438 nm, Cd $226.502 \mathrm{~nm}$, Cd $361.051 \mathrm{~nm}$, Cu 327.396 nm, Fe 275.573 nm, Fe $373.486 \mathrm{~nm}, \mathrm{Ga} 417.206 \mathrm{~nm}$, Li $670.780 \mathrm{~nm}, \mathrm{Li} 460.289 \mathrm{~nm}$, Li $323.261 \mathrm{~nm}, M g 279.553 \mathrm{~nm}$, Mg 280.270 nm, Mg 285.213 nm, Mn $257.611 \mathrm{~nm}$, Mn $259.373 \mathrm{~nm}$, $\mathrm{Na} 330.237 \mathrm{~nm}$, Ni $221.648 \mathrm{~nm}$, Ni $300.249 \mathrm{~nm}, \mathrm{Ni} 341.476 \mathrm{~nm}$, Sr $407.771 \mathrm{~nm}$, Sr $421.552 \mathrm{~nm}$, Sr 460.773 nm, Zn 213.856 nm, Zn 202.613 nm, Cr 205.618 nm, and $\mathrm{Cr} 284.984 \mathrm{~nm}$ lines were interference-free in the presence of $\mathrm{Lu}$ up to $1000 \mathrm{mg} / \mathrm{L}$. The experiment with higher concentrations of $\mathrm{Lu}$ was not carried out to avoid clogging of the nebulizer capillary during sample introduction into the ICP-AES system. The spectral interference of Lu on the abovementioned analytical lines is listed in Table III. For some of the analytes, more than one analytical line showed no spectral interference from Lu. In that case, the analytical performance of these lines then becomes the deciding factor for selecting the best analytical lines of these elements in the Lu matrix.

\section{Ag (Silver)}

Four different analytical lines of $\mathrm{Ag}$ (338.289 nm, $328.068 \mathrm{~nm}$, $224.641 \mathrm{~nm}$ and $243.779 \mathrm{~nm}$ ) were chosen to study the spectral interference of Lu on Ag. Out of these four lines, the $\mathrm{Ag} 338.289 \mathrm{~nm}$ and $328.068 \mathrm{~nm}$ lines were found to be free of spectral interference from Lu. Though both of the lines are suitable for the determination of $\mathrm{Ag}$ in a Lu matrix and on the basis of the analytical performance, the Ag $328.068 \mathrm{~nm}$ line was found to be the best analytical line in a Lu matrix. 


\section{Atomic Spectroscopy \\ Vol. 36(2), March/April 2015}
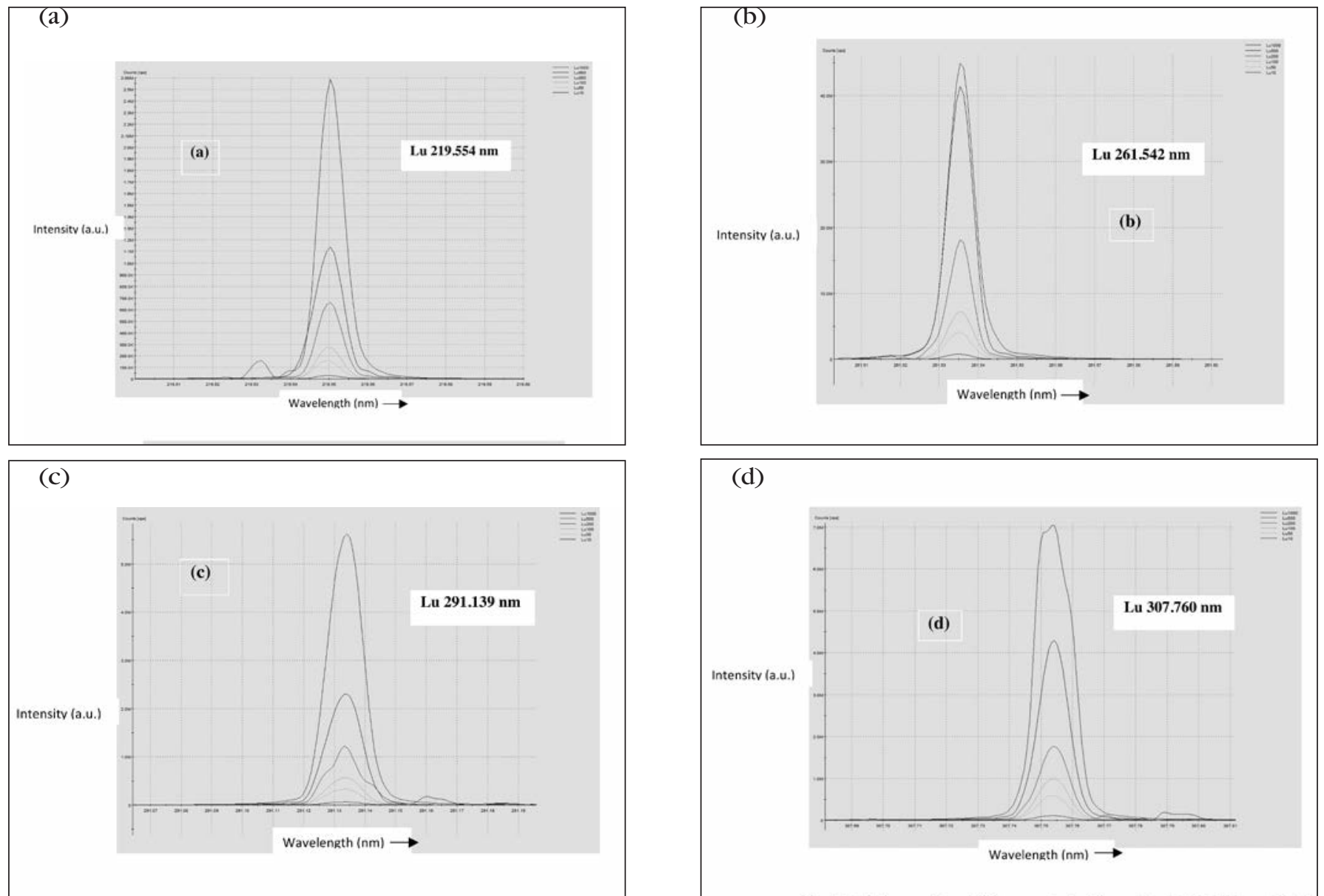

Fig. 1. Emission profiles of different analytical lines of Lu (a) $219.554 \mathrm{~nm}$, (b) $261.542 \mathrm{~nm}$, (c) $291.139 \mathrm{~nm}$, (d) $307.760 \mathrm{~nm}$.

TABLE II

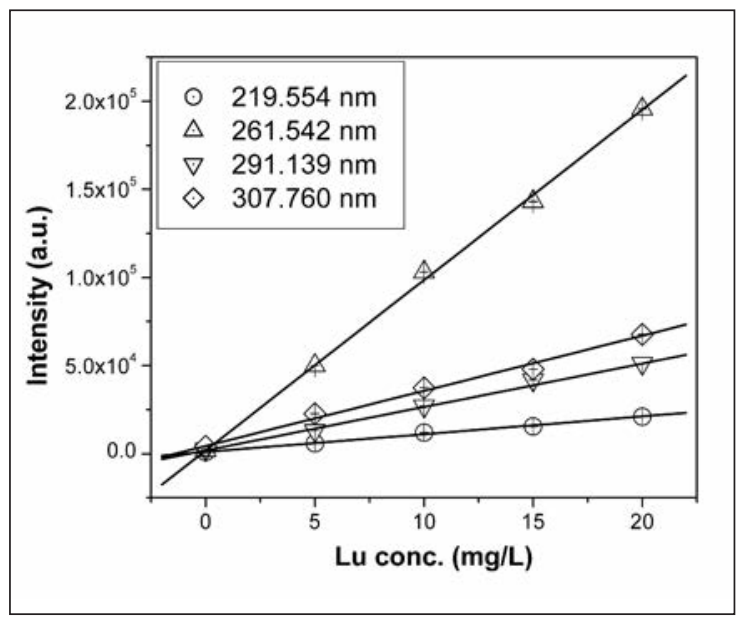

Fig. 2. Calibration curves for different analytical lines of $\mathrm{Lu}$.

Determination of Lu By ICP-AES

\begin{tabular}{lcccc}
\hline $\begin{array}{c}\mathrm{Lu} \\
(\mathrm{mg} / \mathrm{L})\end{array}$ & $\begin{array}{c}261.542 \mathrm{~nm} \\
(\mathrm{mg} / \mathrm{L})\end{array}$ & $\begin{array}{c}291.139 \mathrm{~nm} \\
(\mathrm{mg} / \mathrm{L})\end{array}$ & $\begin{array}{c}307.760 \mathrm{~nm} \\
(\mathrm{mg} / \mathrm{L})\end{array}$ & $\begin{array}{c}219.554 \mathrm{~nm} \\
(\mathrm{mg} / \mathrm{L})\end{array}$ \\
\hline 1 & $0.97 \pm 0.05$ & $0.95 \pm 0.06$ & $1.03 \pm 0.05$ & $1.15 \pm 0.07$ \\
5 & $5.0 \pm 0.07$ & $5.2 \pm 0.11$ & $4.7 \pm 0.09$ & $4.6 \pm 0.07$ \\
10 & $9.8 \pm 0.3$ & $10.4 \pm 0.3$ & $10.2 \pm 0.5$ & $9.5 \pm 0.6$ \\
20 & $19.4 \pm 0.9$ & $18.8 \pm 1.1$ & $21.2 \pm 1.3$ & $21.5 \pm 1.0$ \\
50 & $50 \pm 2$ & $46 \pm 4$ & $51 \pm 3$ & $53 \pm 4$ \\
100 & $102 \pm 4$ & $95 \pm 6$ & $97 \pm 5$ & $103 \pm 6$ \\
500 & $495 \pm 8$ & $492 \pm 9$ & $504 \pm 10$ & $507 \pm 11$ \\
1000 & $993 \pm 13$ & $1018 \pm 17$ & $987 \pm 18$ & $1010 \pm 17$ \\
\hline $\begin{array}{l}\text { D.L. (mg/L) } \\
\text { Sensitivity }\end{array} 9.003$ & 0.042 & 0.042 & 0.081 \\
$($ counts/mg/L) & 2436 & 3180 & 999 \\
Linear Dynamic & & & \\
Range \\
(mg/L)
\end{tabular}


TABLE III

Spectral Interference of Lu on Ag, Al, B, Ba, Bi, Cd, Cr, Cu, Fe, Ga, Li, Mg, Mn, Na, Ni, Sr, and Zn

\begin{tabular}{|c|c|c|c|c|c|c|c|c|c|}
\hline Element & $\begin{array}{l}\text { Analytical } \\
\text { Lines } \\
(\mathrm{nm})\end{array}$ & $\begin{array}{l}\text { Contribution } \\
\text { from } \\
1000 \mathrm{mg} / \mathrm{L} \\
\text { of } \mathrm{Lu}\end{array}$ & $\begin{array}{c}\text { Correction } \\
\text { Factor }\end{array}$ & $\begin{array}{c}\text { Tolerance } \\
\text { Level } \\
(\mathrm{mg} / \mathrm{L})\end{array}$ & Eleme & $\begin{array}{l}\text { Analytical } \\
\text { Lines } \\
(\mathrm{nm})\end{array}$ & $\begin{array}{c}\text { Contribution } \\
\text { from } \\
1000 \mathrm{mg} / \mathrm{L} \\
\text { of } \mathrm{Lu}\end{array}$ & $\begin{array}{c}\text { Correction } \\
\text { Factor }\end{array}$ & $\begin{array}{c}\text { Tolerance } \\
\text { Level } \\
(\mathrm{mg} / \mathrm{L})\end{array}$ \\
\hline \multirow[t]{4}{*}{$\mathrm{Ag}$} & 338.289 & $*$ & - & 1000 & $\mathrm{Ga}$ & 417.206 & * & - & 1000 \\
\hline & 328.068 & $*$ & - & 1000 & & 294.364 & 0.203 & $2.0 \times 10^{-4}$ & 500 \\
\hline & 224.641 & 6.195 & $6.1 \times 10^{-3}$ & 500 & & 287.424 & 0.764 & $7.6 \times 10^{-4}$ & 500 \\
\hline & 243.779 & 0.605 & $6.0 \times 10^{-4}$ & 500 & $\mathrm{Li}$ & 670.78 & $*$ & - & 1000 \\
\hline \multirow[t]{4}{*}{$\mathrm{Al}$} & 396.152 & $*$ & - & 1000 & & 460.289 & * & - & 1000 \\
\hline & 394.401 & $*$ & - & 1000 & & 323.261 & * & - & 1000 \\
\hline & 308.215 & 0.262 & $2.6 \times 10^{-4}$ & 500 & & 274.118 & 7.209 & $7.2 \times 10^{-3}$ & 200 \\
\hline & 309.271 & $*$ & - & 1000 & $\mathrm{Mg}$ & 279.553 & $*$ & - & 1000 \\
\hline \multirow[t]{4}{*}{ B } & 249.773 & 0.062 & $6.2 \times 10^{-5}$ & 1000 & & 280.27 & $*$ & - & 1000 \\
\hline & 249.677 & $*$ & - & 1000 & & 285.213 & $*$ & - & 1000 \\
\hline & 182.641 & 0.123 & $1.2 \times 10^{-4}$ & 500 & & 279.079 & 0.338 & $3.3 \times 10^{-4}$ & 500 \\
\hline & 208.959 & $*$ & - & 1000 & & 202.647 & 0.17 & $1.7 \times 10^{-4}$ & 500 \\
\hline \multirow[t]{3}{*}{$\mathrm{Ba}$} & 455.404 & $*$ & - & 1000 & $\mathrm{Mn}$ & 257.611 & * & - & 1000 \\
\hline & 233.527 & 0.396 & $3.9 \times 10^{-4}$ & 500 & & 259.373 & * & - & 1000 \\
\hline & 230.424 & 0.225 & $2.2 \times 10^{-4}$ & 200 & & 260.569 & 0.098 & $9.8 \times 10^{-5}$ & 500 \\
\hline \multirow[t]{5}{*}{$\mathrm{Bi}$} & 223.061 & 0.543 & $5.4 \times 10^{-4}$ & 200 & & 294.921 & 0.133 & $1.3 \times 10^{-4}$ & 500 \\
\hline & 190.241 & 2.106 & $2.1 \times 10^{-3}$ & 200 & & 403.076 & 0.736 & $7.3 \times 10^{-4}$ & 100 \\
\hline & 306.772 & $*$ & - & 1000 & $\mathrm{Na}$ & 589.592 & 0.066 & $6.6 \times 10^{-5}$ & 1000 \\
\hline & 222.825 & 3.497 & $3.5 \times 10^{-3}$ & 200 & & 588.995 & 0.063 & $6.3 \times 10^{-5}$ & 1000 \\
\hline & 206.17 & 0.95 & $9.5 \times 10^{-4}$ & 200 & & 330.237 & * & - & 1000 \\
\hline \multirow[t]{4}{*}{$\mathrm{Cd}$} & 214.438 & $*$ & - & 1000 & & 330.298 & 4.015 & $4.0 \times 10^{-3}$ & 500 \\
\hline & 226.502 & $*$ & & 1000 & $\mathrm{Ni}$ & 231.604 & 0.17 & $1.7 \times 10^{-4}$ & 500 \\
\hline & 228.802 & 0.074 & $7.4 \times 10^{-5}$ & 500 & & 221.648 & * & - & 1000 \\
\hline & 361.051 & $*$ & & 1000 & & 232.003 & 0.245 & $2.4 \times 10^{-4}$ & 200 \\
\hline \multirow[t]{5}{*}{$\mathrm{Cu}$} & 324.754 & 0.072 & $7.2 \times 10^{-5}$ & 1000 & & 227.021 & 0.294 & $2.9 \times 10^{-4}$ & 200 \\
\hline & 327.396 & $*$ & - & 1000 & & 300.249 & $*$ & - & 1000 \\
\hline & 224.7 & 0.126 & $1.2 \times 10^{-4}$ & 500 & & 341.476 & * & - & 1000 \\
\hline & 219.226 & 2.765 & $2.8 \times 10^{-3}$ & 200 & $\mathrm{Sr}$ & 407.771 & $*$ & - & 1000 \\
\hline & 219.958 & 0.284 & $2.8 \times 10^{-4}$ & 200 & & 421.552 & * & - & 1000 \\
\hline \multirow[t]{10}{*}{$\mathrm{Fe}$} & 259.941 & 0.195 & $1.9 \times 10^{4}$ & 200 & & 460.733 & * & - & 1000 \\
\hline & 238.204 & 0.176 & $1.7 \times 10^{-4}$ & 500 & $\mathrm{Zn}$ & 213.856 & $*$ & - & 1000 \\
\hline & 239.562 & 0.472 & $4.7 \times 10^{-4}$ & 500 & & 206.2 & 0.938 & $9.3 \times 10^{-4}$ & 200 \\
\hline & 244.451 & 1.31 & $1.3 \times 10^{-3}$ & 200 & & 202.613 & * & - & 1000 \\
\hline & 261.187 & 3.663 & $3.7 \times 10^{-3}$ & 10 & & 334.502 & 0.524 & $5.2 \times 10^{-4}$ & 500 \\
\hline & 262.567 & 4.643 & $4.6 \times 10^{-3}$ & 100 & $\mathrm{Cr}$ & 267.716 & 2.702 & $2.7 \times 10^{-3}$ & 50 \\
\hline & 262.829 & 1.724 & $1.7 \times 10^{-3}$ & 200 & & 205.618 & $*$ & - & 1000 \\
\hline & 275.573 & $*$ & - & 1000 & & 283.563 & 0.078 & $7.8 \times 10^{-5}$ & 1000 \\
\hline & 241.331 & 0.556 & $5.5 \times 10^{-4}$ & 500 & & 284.325 & $*$ & - & 1000 \\
\hline & 373.486 & $*$ & - & 1000 & & 284.984 & 0.521 & $5.2 \times 10^{-4}$ & 200 \\
\hline
\end{tabular}

$*=$ No interference. 


\section{Al (Aluminum)}

Of the three interference-free analytical lines of $\mathrm{Al}$, the 309.271 $\mathrm{nm}$ line showed poor detection limit and linear dynamic range, while the best performance was seen for the Al $396.152 \mathrm{~nm}$ line with a detection limit of $0.038 \mathrm{mg} / \mathrm{L}$, sensitivity of 6011 counts $/ \mathrm{mg} / \mathrm{L}$, linear dynamic range of $0.038-1000$ $\mathrm{mg} / \mathrm{L}$, and \%RSD of 1.1. Therefore, the Al $396.152 \mathrm{~nm}$ line can be chosen as the best line for the trace determination of $\mathrm{Al}$ in the presence of a Lu matrix.

\section{B (Boron)}

Among the interference-free two analytical lines of B, the detection limit and the \%RSD of the B $249.677 \mathrm{~nm}$ line was nearly two times higher than the B $208.959 \mathrm{~nm}$ line. Moreover, the sensitivity of the B $208.959 \mathrm{~nm}$ line was also $\sim 4.5$ times higher than the other line; hence, it is the best line for $\mathrm{B}$ in a Lu matrix.

\section{Ba (Barium)}

Even though the interferencefree $\mathrm{Ba} 455.404 \mathrm{~nm}$ line was found to have a higher detection limit than the interfered $\mathrm{Ba} 230.424 \mathrm{~nm}$ line, the sensitivity and precision of the $\mathrm{Ba} 455.404 \mathrm{~nm}$ line were found to be better; hence, it can be chosen for further studies.

\section{Bi (Bismuth)}

The interference-free Bi 306.772 $\mathrm{nm}$ line showed poor detection limit $(2.8 \mathrm{mg} / \mathrm{L})$, while the sensitivity and the \%RSD were found to be the best. The other Bi lines under investigation were significantly interfered by Lu. In this situation, we believe that the Bi 306.772 line can be considered to be the best line for its trace level determination in a Lu matrix.

\section{Cd (Cadmium)}

Of three interference-free analytical lines of Cd, the $361.051 \mathrm{~nm}$ line was found to have poor analytical performance, while the best line was $226.502 \mathrm{~nm}$, with a detection limit of $0.007 \mathrm{mg} / \mathrm{L}$, sensitivity of 9090 counts $/ \mathrm{mg} / \mathrm{L}$, and linear dynamic range up to $100 \mathrm{mg} / \mathrm{L}$ with $\sim 0.8 \%$ RSD.

\section{Cu (Copper) and Ga (Gallium)}

Fortunately for $\mathrm{Cu}$ and $\mathrm{Ga}$, the interference-free analytical lines (Cu 327.396 nm, Ga 417.206 nm) showed the best analytical performance and are unequivocally the best lines in a Lu matrix.

\section{$\mathrm{Na}$ (Sodium)}

The Na $330.237 \mathrm{~nm}$ line showed practically no interference from Lu, yet the analytical performance of the line was not at all satisfactory, i.e., poor detection limit, sensitivity, and precision, with a linear dynamic range up to $700 \mathrm{mg} / \mathrm{L}$. In view of this, the $\mathrm{Na} 588.995 \mathrm{~nm}$ and $589.592 \mathrm{~nm}$ lines showed good analytical performance and are the most suitable lines for $\mathrm{Na}$ in a $\mathrm{Lu}$ matrix even though these lines were slightly interfered by Lu.

\section{$\mathrm{Fe}$ (Iron)}

Of the interference-free lines of Fe (275.573 nm and $373.486 \mathrm{~nm})$, the detection limits of both lines were found to be the same, while the sensitivity, linear dynamic range, and precision of the 373.486 nm line was found to be slightly better than $275.573 \mathrm{~nm}$. Though the Fe $373.486 \mathrm{~nm}$ line was the best line for Fe in a Lu matrix, the overall performance of the 275.573 $\mathrm{nm}$ line was also satisfactory.

\section{Li (Litbium)}

Of the three interference-free analytical lines of $\mathrm{Li}(670.780 \mathrm{~nm}$, $460.289 \mathrm{~nm}$, and $323.260 \mathrm{~nm}), \mathrm{Li}$ $670.780 \mathrm{~nm}$ showed the best analytical performance (detection limit: $0.0014 \mathrm{mg} / \mathrm{L}$, sensitivity: 129515 counts/mg/L, linear dynamic range: $0.0014-1000 \mathrm{mg} / \mathrm{L}$, \%RSD: 0.70) and can, therefore, be considered the most suitable line in a Lu matrix.

\section{Atomic}

\section{Mg (Magnesium)}

For $\mathrm{Mg}$, all three analytical lines were interference-free $(279.553 \mathrm{~nm}$, $280.270 \mathrm{~nm}$ and $285.213 \mathrm{~nm}$ ) with very good analytical performance. Therefore, each of these lines can be used for the determination of $\mathrm{Mg}$ in a Lu matrix, even at trace levels without any separation.

\section{Sr (Strontium)}

For Sr, the analytical performance of the $460.773 \mathrm{~nm}$ line was not as good as that of the other two interference-free analytical lines ( $407.771 \mathrm{~nm}, 421.552 \mathrm{~nm}$ ), the overall performance was also quite satisfactory. Thus, the three lines can be chosen for trace level estimation in a Lu matrix. However, the $\mathrm{Sr} 407.771 \mathrm{~nm}$ and $\mathrm{Sr} 421.552$ $\mathrm{nm}$ lines are considered to be the most suitable.

\section{Mn (Manganese) and Zn (Zinc)}

For the analytes $\mathrm{Mn}$ and $\mathrm{Zn}$, the interference-free analytical lines (Mn 257.611 $\mathrm{nm}$ and $\mathrm{Mn} 259.373$ $\mathrm{nm} ; \mathrm{Zn} 213.856 \mathrm{~nm}$ and $\mathrm{Zn}$ $202.613 \mathrm{~nm}$ ) showed comparable analytical performance; hence, they can be chosen for the trace level determination of $\mathrm{Mn}$ and $\mathrm{Zn}$ in a $\mathrm{Lu}$ matrix.

\section{Cr (Chromium)}

For Cr, the $205.618 \mathrm{~nm}$ analytical line was found to have better analytical performance than $284.984 \mathrm{~nm}$, with a detection limit of $0.0093 \mathrm{mg} / \mathrm{L}$, sensitivity of 2380 counts $/ \mathrm{mg} / \mathrm{L}$, linear dynamic range of $0.0093-1000 \mathrm{mg} / \mathrm{L}$, and a precision of $1.7 \%$ RSD.

\section{Ni (Nickel)}

Of the three interference-free analytical lines of $\mathrm{Ni}(221.648 \mathrm{~nm}$, $300.249 \mathrm{~nm}$, and $341.476 \mathrm{~nm}$ ), the $341.476 \mathrm{~nm}$ line showed the best performance.

The spectral interference of the above-mentioned elements is listed in Table III, while Table IV summarizes their analytical performance. Since the effect of spectral interfer- 
TABLE IV

Analytical Performance of Ag, Al, B, Ba, Bi, Cd, Cr, Cu, Fe, Ga, Li, Mg, Mn, Na, Ni, Sr, and Zn

\begin{tabular}{|c|c|c|c|c|c|c|c|c|c|c|c|}
\hline $\begin{array}{l}\text { Ele- } \\
\text { ments }\end{array}$ & $\begin{array}{l}\text { Analytical } \\
\text { Lines } \\
(\mathrm{nm})\end{array}$ & $\begin{array}{c}\text { D.L. } \\
(\mathrm{mg} / \mathrm{L})\end{array}$ & $\begin{array}{c}\text { Sensitivity } \\
\text { (counts/ } \\
\mathrm{mg} / \mathrm{L} \text { ) }\end{array}$ & $\begin{array}{l}\text { Linear } \\
\text { Dynamic } \\
\text { Range } \\
(\mathrm{mg} / \mathrm{L})\end{array}$ & $\begin{array}{l}(\%) \\
\text { RSD }\end{array}$ & $\begin{array}{c}\text { Ele- } \\
\text { ments }\end{array}$ & $\begin{array}{l}\text { Analytical } \\
\text { Lines } \\
(\mathrm{nm})\end{array}$ & $\begin{array}{l}\text { D.L. } \\
(\mathrm{mg} / \mathrm{L})\end{array}$ & $\begin{array}{c}\text { Sensitivity } \\
\text { (counts/ } \\
\text { mg/L) }\end{array}$ & $\begin{array}{l}\text { Linear } \\
\text { Dynamic } \\
\text { Range } \\
(\mathrm{mg} / \mathrm{L})\end{array}$ & $\begin{array}{l}(\%) \\
\text { RSD }\end{array}$ \\
\hline \multirow[t]{4}{*}{$\mathrm{Ag}$} & 224.641 & 1.1 & 40 & $1.1-580$ & 4.1 & \multirow[t]{3}{*}{ Ga } & 287.424 & 0.69 & 154 & $0.69-700$ & 2.9 \\
\hline & 243.779 & 0.25 & 227 & $0.25-790$ & 2.5 & & 294.364 & 0.11 & 719 & $0.11-900$ & 2.1 \\
\hline & 328.068 & 0.012 & 10714 & $0.012-1000$ & 1.0 & & 417.206 & 0.023 & 4813 & $0.023-1000$ & 1.6 \\
\hline & 338.289 & 0.038 & 5432 & $0.038-1000$ & 1.5 & \multirow[t]{4}{*}{$\mathrm{Li}$} & 274.118 & 1.7 & 33 & $1.7-700$ & 4.7 \\
\hline \multirow[t]{4}{*}{ Al } & 308.215 & 0.063 & 1586 & $0.063-1000$ & 2.1 & & 323.261 & 0.65 & 119 & $0.65-800$ & 4.0 \\
\hline & 309.271 & 1.1 & 2280 & $1.1-800$ & 1.6 & & 460.289 & 0.75 & 136 & $0.75-900$ & 4.1 \\
\hline & 394.401 & 0.061 & 1797 & $0.068-990$ & 1.3 & & 670.78 & 0.0014 & 129515 & $0.0014-1000$ & 0.7 \\
\hline & 396.152 & 0.038 & 6011 & $0.038-1000$ & 1.1 & \multirow[t]{5}{*}{$\mathrm{Mg}$} & 202.647 & 0.035 & 414 & $0.035-800$ & 3.7 \\
\hline \multirow[t]{4}{*}{ B } & 182.641 & 0.019 & 625 & $0.019-800$ & 2.9 & & 279.079 & 0.13 & 331 & $0.13-700$ & 3.1 \\
\hline & 208.959 & 0.056 & 3568 & $0.056-1000$ & 1.0 & & 279.553 & 0.0014 & 52244 & $0.0014-1000$ & 0.9 \\
\hline & 249.677 & 0.097 & 877 & $0.097-800$ & 2.2 & & 280.270 & 0.0012 & 40151 & $0.0012-1000$ & 0.94 \\
\hline & 249.773 & 0.050 & 1305 & $0.050-1000$ & 3.1 & & 285.213 & 0.0018 & 14017 & $0.0018-1000$ & 1.0 \\
\hline \multirow[t]{3}{*}{$\mathrm{Ba}$} & 230.424 & 0.014 & 784 & $0.014-980$ & 3.7 & \multirow[t]{5}{*}{$\mathrm{Mn}$} & 257.611 & 0.007 & 10526 & $0.007-1000$ & 0.9 \\
\hline & 233.527 & 0.24 & 350 & $0.24-500$ & 4.6 & & 259.373 & 0.0091 & 8047 & $0.0091-1000$ & 0.9 \\
\hline & 455.404 & 0.083 & 1439 & $0.083-1000$ & 1.9 & & 260.569 & 0.018 & 5084 & $0.018-950$ & 1.5 \\
\hline \multirow[t]{5}{*}{$\mathrm{Bi}$} & 190.241 & 0.21 & 27 & $0.21-750$ & 4.1 & & 294.921 & 0.084 & 1432 & $0.084-950$ & 1.3 \\
\hline & 206.17 & 0.26 & 66 & $0.26-650$ & 4.0 & & 403.076 & 0.026 & 5889 & $0.026-950$ & 1.2 \\
\hline & 222.825 & 0.39 & 36 & $0.39-800$ & 3.9 & \multirow[t]{3}{*}{$\mathrm{Na}$} & 330.237 & 2.1 & 82 & $2.1-700$ & 4.1 \\
\hline & 223.061 & 0.19 & 285 & $0.19-800$ & 2.6 & & 530.298 & 2.3 & 64 & $2.3-800$ & 4.5 \\
\hline & 306.772 & 2.8 & 1112 & $2.8-800$ & 1.0 & & 588.995 & 0.0051 & 33736 & $0.0051-1000$ & 1.3 \\
\hline \multirow[t]{4}{*}{$\mathrm{Cd}$} & 214.438 & 0.012 & 4193 & $0.012-1000$ & 1.1 & \multirow{7}{*}{$\mathrm{Ni}$} & 589.592 & 0.011 & 21676 & $0.011-1000$ & 2.1 \\
\hline & 226.502 & 0.007 & 9090 & $0.007-1000$ & 0.8 & & 221.648 & 0.14 & 745 & $0.14-800$ & 2.9 \\
\hline & 228.802 & 0.051 & 1897 & $0.051-950$ & 1.5 & & 227.021 & 0.031 & 126 & $0.031-900$ & 3.8 \\
\hline & 361.051 & 0.51 & 193 & $0.51-700$ & 3.1 & & 231.604 & 0.072 & 743 & $0.072-890$ & 3.2 \\
\hline \multirow[t]{5}{*}{$\mathrm{Cu}$} & 219.226 & 0.18 & 330 & $0.18-900$ & 4.2 & & 232.003 & 0.084 & 589 & $0.084-900$ & 3.0 \\
\hline & 219.958 & 0.075 & 672 & $0.075-500$ & 4.0 & & 300.249 & 0.19 & 618 & $0.19-900$ & 2.8 \\
\hline & 224.7 & 0.012 & 1695 & $0.012-800$ & 2.6 & & 341.476 & 0.073 & 2585 & $0.073-990$ & 1.1 \\
\hline & 324.754 & 0.0016 & 39510 & $0.0016-1000$ & 0.8 & \multirow[t]{3}{*}{$\mathrm{Sr}$} & 407.771 & 0.0003 & 215159 & $0.0003-1000$ & 0.8 \\
\hline & 327.396 & 0.002 & 26650 & $0.002-1000$ & 0.8 & & 421.552 & 0.0011 & 168621 & $0.0011-1000$ & 0.9 \\
\hline \multirow[t]{10}{*}{$\mathrm{Fe}$} & 238.204 & 0.049 & 886 & $0.049-675$ & 2.9 & & 460.733 & 0.096 & 1295 & $0.096-800$ & 1.1 \\
\hline & 239.562 & 0.060 & 1684 & $0.060-800$ & 1.9 & \multirow[t]{4}{*}{$\mathrm{Zn}$} & 202.613 & 0.001 & 1740 & $0.001-990$ & 1.7 \\
\hline & 241.331 & 0.45 & 216 & $0.45-500$ & 4.1 & & 206.2 & 0.3 & 149 & $0.3-600$ & 4.1 \\
\hline & 244.451 & 0.43 & 122 & $0.43-500$ & 4.5 & & 213.856 & 0.0045 & 14408 & $0.0045-1000$ & 0.9 \\
\hline & 259.941 & 0.34 & 1586 & $0.34-950$ & 2.7 & & 334.502 & 0.28 & 378 & $0.28-800$ & 3.8 \\
\hline & 261.187 & 0.078 & 931 & $0.078-750$ & 2.6 & \multirow[t]{5}{*}{$\mathrm{Cr}$} & 205.618 & 0.0093 & 2380 & $0.0098-1000$ & 1.7 \\
\hline & 262.567 & 0.46 & 85 & $0.46-900$ & 3.1 & & 267.716 & 0.15 & 560 & $0.15-850$ & 2.8 \\
\hline & 262.829 & 0.28 & 174 & $0.28-900$ & 2.8 & & 283.563 & 0.035 & 2893 & $0.035-1000$ & 1.4 \\
\hline & 275.573 & 0.11 & 260 & $0.11-800$ & 2.6 & & 284.325 & 0.086 & 1363 & $0.086-950$ & 1.9 \\
\hline & 373.486 & 0.11 & 1354 & $0.11-900$ & 2.2 & & 284.984 & 0.088 & 503 & $0.088-800$ & 2.8 \\
\hline
\end{tabular}


ence on the interfered line is a function of the concentration of the interfering element, a systematic study was carried out to understand the effect of Lu concentration on the different interfered analytical lines of the elements. Based on the linear relationship, the correction factors for the different interfered analytical lines were calculated.

\section{Spectral Interference of Lu on Some REEs: Ce, Dy, La, Gd, Nd, and Pr}

Due to the line-rich emission spectra of rare earth elements (REEs), even though additional analytical lines are available, the chance of interference also increases. Moreover, due to the similar chemistry of this group of elements, the trace level determination of REEs in a rare earth matrix becomes very complicated.

\section{Ce (Cesium)}

Four different analytical lines of Ce were chosen for the present study $(393.373 \mathrm{~nm}, 413.765 \mathrm{~nm}$, $418.660 \mathrm{~nm}$, and $413.380 \mathrm{~nm})$. The Ce $418.660 \mathrm{~nm}$ and $413.380 \mathrm{~nm}$ lines were found to be free from the spectral interference of $\mathrm{Lu}$, while the Lu $393.373 \mathrm{~nm}$ line was severely interfered by Lu. The detection limits of these lines were found to be similar with the trend: $413.380 \mathrm{~nm}<413.765 \mathrm{~nm} \sim$ $418.660 \mathrm{~nm}<393.373 \mathrm{~nm}$, whereas the sensitivity followed the trend: $413.380 \mathrm{~nm} \sim 413.765$ $\mathrm{nm}>418.660 \mathrm{~nm}>393.373 \mathrm{~nm}$. The reproducibility was $\geq 3 \%$ RSD. From the above results, it can be concluded that both the Ce $418.660 \mathrm{~nm}$ and $413.380 \mathrm{~nm}$ lines can be used for trace level determination in a Lu matrix.

\section{Dy (Dysprosium)}

In case of Dy, the five analytical lines chosen $(353.170 \mathrm{~nm}, 394.460$ $\mathrm{nm}, 340.780 \mathrm{~nm}, 353.602 \mathrm{~nm}$, and $364.540 \mathrm{~nm}$ ) were free of Lu spectral interference even at trace levels up to $1000 \mathrm{mg} / \mathrm{L}$ concentration of
Lu. The detection limits of these lines followed the order: 364.540 $\mathrm{nm}<353.170 \mathrm{~nm}<394.468 \mathrm{~nm}<$ $340.780 \mathrm{~nm} \sim 353.602 \mathrm{~nm}$, while their sensitivity followed the trend: $353.170 \mathrm{~nm}>364.540 \mathrm{~nm}>$ $340.780 \mathrm{~nm}>394.468 \mathrm{~nm}>$ $353.602 \mathrm{~nm}$. Based on the above study and even though the Dy $353.170 \mathrm{~nm}$ and $364.540 \mathrm{~nm}$ analytical lines were found to the best in a Lu matrix, all of the above-mentioned lines can be used for the trace level determination of Dy in a Lu matrix.

\section{La (Lanthanum)}

For La, three lines $(408.672 \mathrm{~nm}$, $333.749 \mathrm{~nm}$ and $379.478 \mathrm{~nm}$ ) were interference-free from Lu. Surprisingly, the different merits of the analytical performance of these lines, including detection limits, sensitivity, \%RSD, and linear dynamic range, were similar and good. Therefore, all of these lines are suitable in a Lu matrix.

\section{Gd (Gadolinium)}

Among the four analytical lines of Gd (342.247 nm, $335.047 \mathrm{~nm}$, $336.223 \mathrm{~nm}$, and $335.862 \mathrm{~nm}$ ), there was practically no spectral interference from Lu up to 1000 $\mathrm{mg} / \mathrm{L}$. The analytical performance of these lines was highly satisfactory and can be chosen for further investigation. In accordance with the overall performance, the Gd $335.047 \mathrm{~nm}$ line was believed to be the best line for Gd in a Lu matrix.

\section{Nd (Neodymium)}

Of the four analytical lines of $\mathrm{Nd}$ (401.225 nm, $430.358 \mathrm{~nm}, 406.109$ $\mathrm{nm}$, and $417.731 \mathrm{~nm}$ ), only 401.225 nm was slightly interfered by Lu with a tolerance level of $500 \mathrm{mg} / \mathrm{L}$. The detection limit of these lines followed the trend: $401.225 \mathrm{~nm}$ $<430.358 \mathrm{~nm}<406.109 \mathrm{~nm}<$ $417.731 \mathrm{~nm}$, while the reverse trend was seen in case of their sensitivity. Though the analytical performance of all of these lines was good, unfortunately the best per- formed analytical line (401.225 nm) had a slight interference from Lu. Therefore, the rest of the analytical lines were taken as suitable lines for further investigation.

\section{$\operatorname{Pr}$ (Praeseodymium)}

Of the four analytical lines of $\mathrm{Pr}$ (411.846 nm, 417.939 nm, 422.535 $\mathrm{nm}$ and $414.311 \mathrm{~nm}$ ), only two lines ( $417.939 \mathrm{~nm}$ and $422.535 \mathrm{~nm}$ ) were interference-free from Lu up to $1000 \mathrm{mg} / \mathrm{L}$. Though the analytical performance of the $422.535 \mathrm{~nm}$ line was found to be satisfactory, the $\operatorname{Pr} 417.846 \mathrm{~nm}$ line showed the best performance (detection limit: $0.04 \mathrm{mg} / \mathrm{L}$, sensitivity: 2799 counts/mg/L, \% RSD: 1.2 , linear dynamic range: $0.04-1000 \mathrm{mg} / \mathrm{L}$ ), and thus the most suitable choice for $\mathrm{Pr}$ determination in a Lu matrix.

The systematic study and the results of the spectral interference of Lu on these rare earth elements are tabulated in Table $\mathrm{V}$, while the analytical performance of the different analytical lines of these rare earth elements are summarized in Table VI.

\section{Spectral Interference of Lu on $\mathrm{Ca}, \mathrm{Co}, \mathrm{In}, \mathrm{Pb}$, and Tl \\ Ca (Calcium)}

Among six identified analytical lines for Ca $(396.847 \mathrm{~nm}, 393.366$ $\mathrm{nm}, 317.933 \mathrm{~nm}, 315.887 \mathrm{~nm}$, $183.801 \mathrm{~nm}$, and $422.673 \mathrm{~nm}$, the $315.887 \mathrm{~nm}$ line was found to be free of Lu interference, whereas the analytical performance was very poor. On the contrary, one of the best performing analytical lines of $\mathrm{Ca}$, i.e., $396.847 \mathrm{~nm}$, showed appreciable spectral contribution from Lu. Based on the spectral interference as well as the analytical performance, it was observed that the Ca $393.366 \mathrm{~nm}$ and $422.673 \mathrm{~nm}$ lines should be the best lines of choice. 
TABLE V

Spectral Interference Of Lu on Ce, Dy, La, Gd, Pr, and Nd

\begin{tabular}{|c|c|c|c|c|c|c|c|c|c|}
\hline Elemer & $\begin{array}{l}\text { Analytical } \\
\text { Lines } \\
(\mathrm{nm})\end{array}$ & $\begin{array}{c}\text { Contributior } \\
\text { from } \\
1000 \mathrm{mg} / \mathrm{L} \\
\text { of } \mathrm{Lu} \\
\end{array}$ & $\begin{array}{c}\text { Correction } \\
\text { Factor }\end{array}$ & $\begin{array}{l}\text { Tolerance } \\
\text { Level } \\
(\mathrm{mg} / \mathrm{L})\end{array}$ & Element & $\begin{array}{l}\text { Analytical } \\
\text { Lines } \\
(\mathrm{nm})\end{array}$ & $\begin{array}{l}\text { Contribution } \\
\text { from } \\
1000 \mathrm{mg} / \mathrm{L} \\
\text { of } \mathrm{Lu}\end{array}$ & $\begin{array}{c}\text { Correction } \\
\text { Factor }\end{array}$ & $\begin{array}{c}\text { Tolerance } \\
\text { Level } \\
(\mathrm{mg} / \mathrm{L})\end{array}$ \\
\hline \multirow[t]{4}{*}{$\mathrm{Ce}$} & 418.66 & $*$ & - & 1000 & Gd & 342.247 & $*$ & - & 1000 \\
\hline & 413.765 & 0.302 & $3.0 \times 10^{-4}$ & 500 & & 335.047 & * & - & 1000 \\
\hline & 413.38 & $*$ & - & 1000 & & 336.223 & $*$ & - & 1000 \\
\hline & 393.373 & 15.204 & $1.5 \times 10^{-2}$ & 0.05 & & 335.862 & $*$ & - & 1000 \\
\hline \multirow[t]{5}{*}{ Dy } & 353.17 & $*$ & - & 1000 & $\mathrm{Nd}$ & 401.225 & 0.286 & $2.8 \times 10^{-4}$ & 500 \\
\hline & 394.468 & $*$ & - & 1000 & & 430.358 & $*$ & - & 1000 \\
\hline & 340.78 & $*$ & - & 1000 & & 406.109 & $*$ & - & 1000 \\
\hline & 353.602 & $*$ & - & 1000 & & 417.731 & * & - & 1000 \\
\hline & 364.54 & $*$ & - & 1000 & $\operatorname{Pr}$ & 411.846 & 0.425 & $4.2 \times 10^{-4}$ & 200 \\
\hline \multirow[t]{3}{*}{$\mathrm{La}$} & 408.672 & $*$ & - & 1000 & & 417.939 & $*$ & - & 1000 \\
\hline & 333.749 & $*$ & - & 1000 & & 422.535 & $*$ & - & 1000 \\
\hline & 379.478 & $*$ & - & 1000 & & 414.311 & 0.134 & $1.3 \times 10^{-4}$ & 500 \\
\hline
\end{tabular}

$*=$ No interference.

TABLE VI

Analytical Performance of Ce, Dy, La, Gd, Pr, and Nd

\begin{tabular}{|c|c|c|c|c|c|c|c|c|c|c|c|}
\hline $\begin{array}{l}\text { Ele- } \\
\text { ments }\end{array}$ & $\begin{array}{l}\text { Analytical } \\
\text { Lines } \\
\text { (nm) }\end{array}$ & $\begin{array}{l}\text { D.L. } \\
(\mathrm{mg} / \mathrm{L})\end{array}$ & $\begin{array}{l}\text { Sensitivity } \\
\text { (counts/ } \\
\mathrm{mg} / \mathrm{L})\end{array}$ & $\begin{array}{l}\text { Linear } \\
\text { Dynamic } \\
\text { Range } \\
(\mathrm{mg} / \mathrm{L})\end{array}$ & $\begin{array}{l}(\%) \\
\text { RSD }\end{array}$ & $\begin{array}{c}\text { Ele- } \\
\text { ments }\end{array}$ & $\begin{array}{l}\text { Analytical } \\
\text { Lines } \\
\text { (nm) }\end{array}$ & $\underset{(\mathrm{mg} / \mathrm{L})}{\mathrm{D})}$ & $\begin{array}{l}\text { Sensitivity } \\
\text { (counts/ } \\
\text { mg/L) }\end{array}$ & $\begin{array}{l}\text { Linear } \\
\text { Dynamic } \\
\text { Range } \\
(\mathrm{mg} / \mathrm{L})\end{array}$ & $\begin{array}{l}\text { (\%) } \\
\text { RSD }\end{array}$ \\
\hline \multirow[t]{4}{*}{$\mathrm{Ce}$} & 393.373 & 0.21 & 1260 & $0.21-900$ & 2.5 & \multirow[t]{4}{*}{$\mathrm{Nd}$} & 401.225 & 0.081 & 1821 & $0.081-1000$ & 2.6 \\
\hline & 413.38 & 0.12 & 1539 & $0.12-1000$ & 2.3 & & 406.109 & 0.16 & 1206 & $0.16-1000$ & 2.3 \\
\hline & 413.765 & 0.15 & 1528 & $0.15-1000$ & 2.1 & & 417.731 & 0.25 & 1203 & $0.25-1000$ & 2.1 \\
\hline & 418.66 & 0.16 & 1277 & $0.16-990$ & 3.1 & & 430.358 & 0.098 & 1748 & $0.098-1000$ & 1.8 \\
\hline \multirow[t]{5}{*}{ Dy } & 340.78 & 0.057 & 3565 & $0.057-1000$ & 2.6 & \multirow[t]{4}{*}{$\operatorname{Pr}$} & 411.846 & 0.08 & 2440 & $0.08-800$ & 2.9 \\
\hline & 353.17 & 0.017 & 10816 & $0.017-1000$ & 0.9 & & 414.311 & 0.06 & 3013 & $0.06-1000$ & 1.5 \\
\hline & 353.602 & 0.053 & 2890 & $0.053-900$ & 2.1 & & 417.939 & 0.04 & 2799 & 0.04-1000 & 1.2 \\
\hline & 364.54 & 0.011 & 4402 & $0.011-1000$ & 1.6 & & 422.535 & 0.097 & 2154 & $0.097-1000$ & 1.1 \\
\hline & 394.468 & 0.039 & 3027 & $0.039-900$ & 2.5 & \multirow[t]{4}{*}{ Gd } & 335.047 & 0.015 & 5115 & $0.015-1000$ & 1.2 \\
\hline \multirow[t]{3}{*}{$\mathrm{La}$} & 333.749 & 0.038 & 4051 & $0.038-1000$ & 1.7 & & 335.862 & 0.075 & 3320 & $0.075-950$ & 2.0 \\
\hline & 379.478 & 0.044 & 4462 & $0.044-1000$ & 1.9 & & 336.223 & 0.079 & 3862 & $0.079-1000$ & 1.8 \\
\hline & 408.672 & 0.042 & 4789 & $0.042-1000$ & 1.5 & & 342.247 & 0.034 & 3502 & $0.034-1000$ & 1.7 \\
\hline
\end{tabular}




\section{Co (Cobalt)}

A difficult situation arises for Co. The spectral contribution from $\mathrm{Lu}$ followed the trend: $237.862 \mathrm{~nm}$ $<228.616 \mathrm{~nm}<230.786 \mathrm{~nm}<$ $238.892 \mathrm{~nm}$. The tolerance level was found to be $500 \mathrm{mg} / \mathrm{L}$ of $\mathrm{Lu}$ for all of the lines, except for Co $238.892 \mathrm{~nm}$, with a tolerance level of $200 \mathrm{mg} / \mathrm{L}$. The detection limits of these lines follow the trend: $237.862 \mathrm{~nm} \sim 238.892 \mathrm{~nm}<$ $228.616 \mathrm{~nm} \sim 230.786 \mathrm{~nm}$, whereas the sensitivity followed: $238.892 \mathrm{~nm}>237.862 \mathrm{~nm}>$ $228.616 \mathrm{~nm}>230.786 \mathrm{~nm}$. Based on the above analysis, the Co $237.862 \mathrm{~nm}$ and $238.892 \mathrm{~nm}$ lines were chosen as the best lines in a Lu matrix for further investigation.

\section{In (Indium)}

For In, four different analytical lines were chosen $(230.606 \mathrm{~nm}$, $303.936 \mathrm{~nm}, 325.609 \mathrm{~nm}$, and $451.131 \mathrm{~nm})$. It was observed that

\section{Atomic Spectroscopy \\ $\bigcirc$ Vol. 36(2), March/April 2015}

TABLE VII the interference-free analytical line of $451.131 \mathrm{~nm}$ showed very poor analytical performance, while the other three lines showed similar contribution from $1000 \mathrm{mg} / \mathrm{L}$ of $\mathrm{Lu}$.

The spectral interference of $\mathrm{Lu}$ on $\mathrm{Ca}, \mathrm{Co}, \mathrm{In}, \mathrm{Pb}$, and $\mathrm{Tl}$ are tabulated in Table VII, while the analytical performance of the different analytical lines of these elements is summarized in Table VIII.

Spectral Interference of $\mathrm{Lu}$ on $\mathrm{Ca}, \mathrm{Co}, \mathrm{In}, \mathrm{Pb}$, and $\mathrm{Tl}$

\begin{tabular}{|c|c|c|c|c|c|c|c|c|c|}
\hline Elemen & $\begin{array}{l}\text { Analytical } \\
\text { Lines } \\
(\mathrm{nm})\end{array}$ & \multicolumn{2}{|l|}{$\begin{array}{l}\text { Contribution } \\
\text { from }\end{array}$} & $\begin{array}{c}\text { Tolerance } \\
\text { Level } \\
\text { (mg/L) }\end{array}$ & Elemer & $\begin{array}{l}\text { Analytical } \\
\text { Lines } \\
(\mathrm{nm})\end{array}$ & $\begin{array}{c}\text { Contribution } \\
\text { from } \\
1000 \mathrm{mg} / \mathrm{L} \\
\text { of } \mathrm{Lu}\end{array}$ & $\begin{array}{l}\text { Correction } \\
\text { Factor }\end{array}$ & $\begin{array}{c}\text { Tolerance } \\
\text { Level } \\
(\mathrm{mg} / \mathrm{L})\end{array}$ \\
\hline \multirow[t]{6}{*}{$\mathrm{Ca}$} & 396.847 & 0.376 & $3.8 \times 10^{-4}$ & 100 & In & 230.606 & 0.284 & $2.8 \times 10^{-4}$ & 500 \\
\hline & 393.366 & 0.292 & $2.9 \times 10^{-4}$ & 100 & & 325.609 & 0.192 & $1.9 \times 10^{-4}$ & 500 \\
\hline & 317.933 & 0.303 & $3.0 \times 10^{-4}$ & 200 & & 451.131 & $*$ & - & 1000 \\
\hline & 315.887 & * & - & 1000 & & 303.936 & 0.322 & $3.2 \times 10^{-4}$ & 500 \\
\hline & 183.801 & 4.423 & $4.4 \times 10^{-3}$ & 500 & $\mathrm{~Pb}$ & 220.353 & 1.106 & $1.1 \times 10^{-3}$ & 200 \\
\hline & 422.673 & 0.162 & $1.6 \times 10^{-4}$ & 200 & & 405.778 & 0.312 & $3.1 \times 10^{-4}$ & 500 \\
\hline \multirow[t]{4}{*}{$\mathrm{Co}$} & 228.616 & 0.17 & $1.7 \times 10^{-4}$ & 500 & & 283.305 & 0.251 & $2.5 \times 10^{-4}$ & 200 \\
\hline & 238.892 & 0.31 & $3.1 \times 10^{-4}$ & 200 & & 261.418 & $\#$ & Rejected & - \\
\hline & 230.786 & 0.25 & $2.5 \times 10^{-4}$ & 500 & $\mathrm{Tl}$ & 190.864 & 0.117 & $1.2 \times 10^{-4}$ & 500 \\
\hline & 237.862 & 0.096 & $9.6 \times 10^{-5}$ & 500 & & 276.787 & 3.753 & $3.8 \times 10^{-3}$ & 500 \\
\hline
\end{tabular}

\footnotetext{
* = No interference, $\#$ = Significant interference.
}

TABLE VIII

Analytical Performance of $\mathrm{Ca}, \mathrm{Co}, \mathrm{In}, \mathrm{Pb}$, and T1

\begin{tabular}{|c|c|c|c|c|c|c|c|c|c|c|c|}
\hline $\begin{array}{l}\text { Ele- } \\
\text { ments }\end{array}$ & $\begin{array}{l}\text { Analytical } \\
\text { Lines } \\
\text { (nm) }\end{array}$ & $\begin{array}{c}\text { D.L. } \\
(\mathrm{mg} / \mathrm{L})\end{array}$ & $\begin{array}{l}\text { Sensitivity } \\
\text { (counts/ } \\
\text { mg/L) }\end{array}$ & $\begin{array}{c}\text { Linear } \\
\text { Dynamic } \\
\text { Range } \\
(\mathrm{mg} / \mathrm{L})\end{array}$ & $\begin{array}{l}(\%) \\
\text { RSD }\end{array}$ & $\begin{array}{l}\text { Ele- } \\
\text { ments }\end{array}$ & $\begin{array}{l}\text { Analytical } \\
\text { Lines } \\
\text { (nm) }\end{array}$ & $\begin{array}{c}\text { D.L. } \\
(\mathrm{mg} / \mathrm{L})\end{array}$ & $\begin{array}{l}\text { Sensitivity } \\
\text { (counts/ } \\
\mathrm{mg} / \mathrm{L} \text { ) }\end{array}$ & $\begin{array}{l}\text { Linear } \\
\text { Dynamic } \\
\text { Range } \\
(\mathrm{mg} / \mathrm{L})\end{array}$ & $\begin{array}{l}(\%) \\
\text { RSD }\end{array}$ \\
\hline \multirow[t]{6}{*}{$\mathrm{Ca}$} & 183.801 & 3.1 & 17 & $3.1-800$ & 4.1 & \multirow[t]{4}{*}{ In } & 230.606 & 0.13 & 425 & $0.13-950$ & 2.1 \\
\hline & 315.887 & 0.2 & 848 & $0.2-800$ & 3.8 & & 303.936 & 0.14 & 448 & $0.14-950$ & 2.0 \\
\hline & 317.933 & 0.048 & 2738 & $0.048-900$ & 2.7 & & 325.609 & 0.095 & 1201 & $0.095-1000$ & 1.5 \\
\hline & 393.366 & 0.0016 & 306574 & $0.0016-1000$ & 1.3 & & 451.131 & 4.9 & 61 & $4.9-800$ & 4.4 \\
\hline & 396.847 & 0.0007 & 226491 & $0.0007-1000$ & 1.2 & \multirow[t]{4}{*}{$\mathrm{Pb}$} & 220.353 & 0.34 & 236 & $0.34-800$ & 2.8 \\
\hline & 422.673 & 0.0024 & 15538 & $0.0024-1000$ & 1.1 & & 261.418 & 0.052 & 98 & $0.052-1000$ & 4.1 \\
\hline \multirow[t]{4}{*}{ Co } & 228.616 & 0.10 & 747 & $0.10-800$ & 2.2 & & 283.305 & 0.049 & 580 & $0.049-1000$ & 1.2 \\
\hline & 230.786 & 0.15 & 555 & $0.15-850$ & 2.8 & & 405.778 & 0.2 & 509 & $0.2-950$ & 2.1 \\
\hline & 237.862 & 0.044 & 1295 & $0.044-1000$ & 9.6 & \multirow[t]{2}{*}{$\mathrm{Tl}$} & 190.864 & 0.083 & 597 & $0.083-1000$ & 3.1 \\
\hline & 238.892 & 0.047 & 1761 & $0.047-1000$ & 1.1 & & 276.787 & 1.8 & 27 & $1.8-900$ & 4.3 \\
\hline
\end{tabular}




\section{Direct Determination of Analytes in a Lu Matrix Without Chemical Separation: Validation Using Synthetic Samples}

Based on these studies, a methodology was developed for the trace level determination of the above-mentioned analytes without chemical separation using synthetic samples prepared from the SRMs of the individual element solutions. The content of each synthetic sample was as followed:

(a) Synthetic sample 1 (S 1): $0.1 \mathrm{mg} / \mathrm{L}$ of $\mathrm{Ag}, \mathrm{Al}, \mathrm{B}, \mathrm{Ba}, \mathrm{Bi}, \mathrm{Cd}$, $\mathrm{Cu}, \mathrm{Fe}, \mathrm{Ga}, \mathrm{Li}, \mathrm{Mg}, \mathrm{Mn}, \mathrm{Na}, \mathrm{Ni}, \mathrm{Sr}$, $\mathrm{Zn}$, and $\mathrm{Cr}$ in $1000 \mathrm{mg} / \mathrm{L}$ of $\mathrm{Lu}$.

(b) Synthetic sample 2 (S 2): $1 \mathrm{mg} / \mathrm{L}$ of $\mathrm{Ag}, \mathrm{Al}, \mathrm{B}, \mathrm{Ba}, \mathrm{Bi}, \mathrm{Cd}, \mathrm{Cu}$, $\mathrm{Fe}, \mathrm{Ga}, \mathrm{Li}, \mathrm{Mg}, \mathrm{Mn}, \mathrm{Na}, \mathrm{Ni}, \mathrm{Sr}, \mathrm{Zn}$, and $\mathrm{Cr}$ in $1000 \mathrm{mg} / \mathrm{L}$ of $\mathrm{Lu}$.

(c) Synthetic sample 3 (S 3): $0.1 \mathrm{mg} / \mathrm{L}$ of Ce, Dy, La, Gd, Nd, and $\mathrm{Pr}$ in $1000 \mathrm{mg} / \mathrm{L}$ of Lu.

(d) Synthetic sample 4 (S 4): $1 \mathrm{mg} / \mathrm{L}$ of Ce, Dy, La, Gd, Nd, and $\mathrm{Pr}$ in $1000 \mathrm{mg} / \mathrm{L}$ of $\mathrm{Lu}$.

(e) Synthetic sample 5 (S 5): $0.2 \mathrm{mg} / \mathrm{L}$ of $\mathrm{Ca}, \mathrm{Co}, \mathrm{In}, \mathrm{Pb}$, and $\mathrm{Tl}$ in $1000 \mathrm{mg} / \mathrm{L}$ of $\mathrm{Lu}$.

(f) Synthetic sample 6 (S 6): $2 \mathrm{mg} / \mathrm{L}$ of $\mathrm{Ca}, \mathrm{Co}, \mathrm{In}, \mathrm{Pb}$, and $\mathrm{Tl}$ in $1000 \mathrm{mg} / \mathrm{L}$ of $\mathrm{Lu}$.

The synthetic samples were of analytes using the best analytical lines of these elements as obtained above. The analytical results revealed that the common analytes (Ag, Al, B, Ba, Bi, Cd, Cu, Fe, Ga, Li, $\mathrm{Mg}, \mathrm{Mn}, \mathrm{Na}, \mathrm{Ni}, \mathrm{Sr}, \mathrm{Zn}$, and $\mathrm{Cr}$ ) can be determined in a Lu matrix without any separation and without any correction factor, even at $0.1 \mathrm{mg} / \mathrm{L}$. Similar results were obtained for the rare earth elements Ce, Dy, La, $\mathrm{Gd}, \mathrm{Nd}$, and Pr. For analytes such as $\mathrm{Ca}, \mathrm{Co}, \mathrm{In}, \mathrm{Pb}$, and $\mathrm{Tl}$, the method is useful for the determination of these elements at the $0.2 \mathrm{mg} / \mathrm{L}$ level in the presence of $1000 \mathrm{mg} / \mathrm{L}$ of Lu. The analytical results of the synthetic samples are listed in Tables IX - XI.

\section{Comparison of Present Method With Other Analytical Methods}

A comparison of the present methodology was carried out with atomic absorption spectrometry and d.c. arc AES. The synthetic

TABLE IX

Analyses of Ag, Al, B, Ba, Bi, Cd, Cr, Cu, Fe, Ga, Li, Mg, Mn, Na, Ni, Sr, and Zn Using Synthetic Samples Prepared

From Commercially Available Standard Reference Materials

\begin{tabular}{|c|c|c|c|c|c|}
\hline \multirow[b]{2}{*}{ Element } & \multirow[b]{2}{*}{$\begin{array}{l}\text { Analytical } \\
\text { Lines }\end{array}$} & \multicolumn{2}{|r|}{ S1 } & \multicolumn{2}{|c|}{ S2 } \\
\hline & & $\begin{array}{l}\text { Actual } \\
\text { Concen- } \\
\text { tration } \\
(\mathrm{mg} / \mathrm{L}) \\
\end{array}$ & $\begin{array}{l}\text { Amount } \\
\text { Estimated After } \\
\text { Incorporating } \\
\text { Correction } \\
\text { Factor } \\
(\mathrm{mg} / \mathrm{L})\end{array}$ & $\begin{array}{c}\text { Actual } \\
\text { Concen- } \\
\text { tration } \\
(\mathrm{mg} / \mathrm{L})\end{array}$ & $\begin{array}{c}\text { Amount } \\
\text { Estimated After } \\
\text { Incorporating } \\
\text { Correcton } \\
\text { Factor } \\
(\mathrm{mg} / \mathrm{L})\end{array}$ \\
\hline \multirow[t]{2}{*}{$\mathrm{Ag}$} & 328.068 & 0.1 & $0.104 \pm 0.004$ & 1 & $1.02 \pm 0.05$ \\
\hline & 338.289 & 0.1 & $0.094 \pm 0.006$ & 1 & $0.97 \pm 0.06$ \\
\hline \multirow[t]{2}{*}{$\mathrm{Al}$} & 396.152 & 0.1 & $0.097 \pm 0.005$ & 1 & $0.95 \pm 0.05$ \\
\hline & 394.401 & 0.1 & $0.102 \pm 0.004$ & 1 & $0.92 \pm 0.07$ \\
\hline \multirow[t]{2}{*}{ B } & 208.959 & 0.1 & $0.110 \pm 0.008$ & 1 & $1.03 \pm 0.03$ \\
\hline & 249.677 & 0.1 & $0.103 \pm 0.004$ & 1 & $1.07 \pm 0.06$ \\
\hline $\mathrm{Ba}$ & 455.404 & 0.1 & $0.097 \pm 0.005$ & 1 & $0.94 \pm 0.04$ \\
\hline $\mathrm{Bi}$ & 306.772 & 0.1 & $0.096 \pm 0.007$ & 1 & $0.98 \pm 0.04$ \\
\hline \multirow[t]{2}{*}{$\mathrm{Cd}$} & 214.438 & 0.1 & $0.104 \pm 0.004$ & 1 & $0.99 \pm 0.06$ \\
\hline & 226.502 & 0.1 & $0.101 \pm 0.003$ & 1 & $0.97 \pm 0.05$ \\
\hline $\mathrm{Cr}$ & 205.618 & 0.1 & $0.098 \pm 0.005$ & 1 & $0.98 \pm 0.06$ \\
\hline $\mathrm{Cu}$ & 327.396 & 0.1 & $0.093 \pm 0.007$ & 1 & $1.03 \pm 0.06$ \\
\hline \multirow[t]{2}{*}{$\mathrm{Fe}$} & 373.486 & 0.1 & $0.107 \pm 0.006$ & 1 & $1.04 \pm 0.07$ \\
\hline & 275.573 & 0.1 & $0.097 \pm 0.004$ & 1 & $1.06 \pm 0.07$ \\
\hline $\mathrm{Ga}$ & 417.206 & 0.1 & $0.096 \pm 0.006$ & 1 & $1.04 \pm 0.05$ \\
\hline $\mathrm{Li}$ & 670.78 & 0.1 & $0.103 \pm 0.005$ & 1 & $1.02 \pm 0.04$ \\
\hline \multirow[t]{3}{*}{$\mathrm{Mg}$} & 279.553 & 0.1 & $0.104 \pm 0.004$ & 1 & $1.03 \pm 0.04$ \\
\hline & 280.27 & 0.1 & $0.104 \pm 0.004$ & 1 & $1.03 \pm 0.05$ \\
\hline & 285.213 & 0.1 & $0.104 \pm 0.004$ & 1 & $1.07 \pm 0.05$ \\
\hline \multirow[t]{2}{*}{ Mn } & 257.611 & 0.1 & $0.104 \pm 0.004$ & 1 & $1.04 \pm 0.06$ \\
\hline & 259.373 & 0.1 & $0.104 \pm 0.004$ & 1 & $1.03 \pm 0.06$ \\
\hline \multirow[t]{2}{*}{$\mathrm{Na}$} & 588.995 & 0.1 & $0.104 \pm 0.004$ & 1 & $1.06 \pm 0.07$ \\
\hline & 589.592 & 0.1 & $0.104 \pm 0.004$ & 1 & $1.03 \pm 0.07$ \\
\hline \multirow[t]{3}{*}{$\mathrm{Ni}$} & 221.648 & 0.1 & $0.104 \pm 0.004$ & 1 & $1.06 \pm 0.06$ \\
\hline & 300.249 & 0.1 & $0.104 \pm 0.004$ & 1 & $0.98 \pm 0.06$ \\
\hline & 341.476 & 0.1 & $0.104 \pm 0.004$ & 1 & $0.94 \pm 0.05$ \\
\hline \multirow[t]{3}{*}{$\mathrm{Sr}$} & 407.771 & 0.1 & $0.104 \pm 0.004$ & 1 & $0.97 \pm 0.08$ \\
\hline & 421.552 & 0.1 & $0.104 \pm 0.004$ & 1 & $0.97 \pm 0.08$ \\
\hline & 460.733 & 0.1 & $0.104 \pm 0.004$ & 1 & $0.96 \pm 0.07$ \\
\hline \multirow[t]{2}{*}{$\mathrm{Zn}$} & 202.613 & 0.1 & $0.104 \pm 0.004$ & 1 & $0.98 \pm 0.07$ \\
\hline & 213.856 & 0.1 & $0.104 \pm 0.004$ & 1 & $1.02 \pm 0.05$ \\
\hline
\end{tabular}


TABLE $X$

Analyses of Ce, Dy, La, Gd, Pr, and Nd Using Synthetic Samples Prepared From Commercially Available Standard Reference Materials

\begin{tabular}{|c|c|c|c|c|c|}
\hline \multirow[b]{2}{*}{ Elements } & \multirow[b]{2}{*}{$\begin{array}{l}\text { Analytical } \\
\text { Lines }\end{array}$} & \multicolumn{2}{|c|}{ S3 } & \multicolumn{2}{|c|}{ S4 } \\
\hline & & $\begin{array}{l}\text { Actual } \\
\text { Concen- } \\
\text { tration } \\
\\
(\mathrm{mg} / \mathrm{L})\end{array}$ & $\begin{array}{c}\text { Amount } \\
\text { Estimated After } \\
\text { Incorporating } \\
\text { Correction } \\
\text { Factor } \\
(\mathrm{mg} / \mathrm{L}) \\
\end{array}$ & $\begin{array}{c}\text { Actual } \\
\text { Concen- } \\
\text { tration } \\
(\mathrm{mg} / \mathrm{L})\end{array}$ & $\begin{array}{c}\text { Amount } \\
\text { Estimated After } \\
\text { Incorporating } \\
\text { Correcton } \\
\text { Factor } \\
(\mathrm{mg} / \mathrm{L} \\
\end{array}$ \\
\hline \multirow[t]{2}{*}{$\mathrm{Ce}$} & 413.38 & 0.1 & $0.096 \pm 0.004$ & 1 & $1.01 \pm 0.05$ \\
\hline & 418.66 & 0.1 & $0.102 \pm 0.03$ & 1 & $0.97 \pm 0.06$ \\
\hline \multirow[t]{3}{*}{$\mathrm{La}$} & 408.672 & 0.1 & $0.101 \pm 0.005$ & 1 & $0.96 \pm 0.07$ \\
\hline & 333.749 & 0.1 & $0.097 \pm 0.003$ & 1 & $0.94 \pm 0.06$ \\
\hline & 379.478 & 0.1 & $0.095 \pm 0.005$ & 1 & $1.12 \pm 0.06$ \\
\hline \multirow[t]{4}{*}{ Gd } & 342.247 & 0.1 & $0.096 \pm 0.05$ & 1 & $0.97 \pm 0.07$ \\
\hline & 335.047 & 0.1 & $0.103 \pm 0.004$ & 1 & $1.10 \pm 0.06$ \\
\hline & 336.223 & 0.1 & $0.102 \pm 0.004$ & 1 & $1.05 \pm 0.06$ \\
\hline & 335.862 & 0.1 & $0.107 \pm 0.005$ & 1 & $1.07 \pm 0.07$ \\
\hline \multirow[t]{3}{*}{$\mathrm{Nd}$} & 430.358 & 0.1 & $0.11 \pm 0.006$ & 1 & $1.06 \pm 0.04$ \\
\hline & 406.109 & 0.1 & $0.095 \pm 0.004$ & 1 & $0.98 \pm 0.04$ \\
\hline & 417.731 & 0.1 & $0.099 \pm 0.004$ & 1 & $0.95 \pm 0.03$ \\
\hline \multirow[t]{2}{*}{$\operatorname{Pr}$} & 417.939 & 0.1 & $0.098 \pm 0.003$ & 1 & $0.99 \pm 0.05$ \\
\hline & 422.535 & 0.1 & $0.098 \pm 0.003$ & 1 & $1.04 \pm 0.07$ \\
\hline \multirow[t]{5}{*}{ Dy } & 353.17 & 0.1 & $0.097 \pm 0.004$ & 1 & $1.04 \pm 0.05$ \\
\hline & 394.468 & 0.1 & $0.96 \pm 0.04$ & 1 & $1.05 \pm 0.04$ \\
\hline & 340.78 & 0.1 & $0.96 \pm 0.04$ & 1 & $0.95 \pm 0.07$ \\
\hline & 364.54 & 0.1 & $0.96 \pm 0.04$ & 1 & $0.97 \pm 0.05$ \\
\hline & 413.38 & 0.1 & $0.96 \pm 0.04$ & 1 & $0.96 \pm 0.03$ \\
\hline
\end{tabular}

samples containing $0.3 \mathrm{mg} / \mathrm{L}$ of $\mathrm{Ag}, \mathrm{Al}, \mathrm{B}, \mathrm{Ba}, \mathrm{Bi}, \mathrm{Cd}, \mathrm{Cu}, \mathrm{Fe}, \mathrm{Ga}, \mathrm{Li}$, $\mathrm{Mg}, \mathrm{Mn}, \mathrm{Na}, \mathrm{Ni}, \mathrm{Sr}, \mathrm{Zn}$, and $\mathrm{Cr}$ and $1.5 \mathrm{mg} / \mathrm{L}$ of $\mathrm{Ca}, \mathrm{Co}, \mathrm{In}, \mathrm{Pb}$, and $\mathrm{Tl}$ in $1000 \mathrm{mg} / \mathrm{L}$ of Lu were directly fed into the plasma and the analytical results were compared with the results obtained from the d.c. arc carrier distillation technique (45) for all of the analytes, except Ag. For Ag, the atomic absorption spectrometric technique was used for comparison purposes (46). Table XII shows good agreement between the comparative techniques. For the rare earth elements $\mathrm{La}, \mathrm{Ce}, \mathrm{Pr}$, $\mathrm{Nd}$, Dy, and Gd, separate synthetic samples were prepared containing

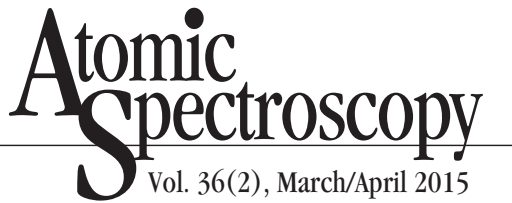

these elements in the presence of a Lu matrix were identified. A new approach was adopted for the direct determination of these analytes using ICP-AES at trace levels in the presence of a Lu matrix without chemical separation. This newly developed method was found to be simple, precise, sensitive, and less time-consuming. Furthermore, the developed methodology was validated using synthetic samples prepared from commercially available standard reference material solutions of each element, and the results were found to be satisfactory. The method was also compared with other existing techniques such as d.c. arc, ion chromatography, and atomic absorption spectrometry. Moreover, an ICP-AESbased method for the simultaneous determination of Lu revealed that the $\mathrm{Lu} 261.542 \mathrm{~nm}$ line is the best line for its determination.

Received August 4, 2014.

\section{REFERENCES}

1. Greenfield, H. McD. McGeachin and P. B. Smith, Talanta 23, 1 (1976).

2. P. W. J. M. Bowmans, Fresenius Z. Anal. Chem. 299, 337 (1979).

3. R. M. Barnes, CRC Crit. Rev. Anal. Chem. 7, 203 (1978).

4. J. P. Robin, Pro. Anal. At Spectrosc. 5, 79 (1982).

5. A. V. Kiselev, N. V. Kovaleva, and Y. S. Nikitin, J. Chromatogr. 58, 19 (1971).

6. F. Bruner, P. Ciccioli, G. Crescentini and M. T. Pistolesi, Anal. Chem. 45, 1851(1973).

7. A. DiCorcia and A. Liberti. Adv. Chromatogr. 14,305 (1974).

8. J. Mora, S. Maestre, V. Hernandis and J. L. Todoli, Liquid Ssample Intro. in Plasma Spectrom. 22, 123 (2003).

9. J. L. Todolí and J.M. Mermet, Spectrochim. Acta, Part B 54, 895(1999).

10. J. L. Todolí, L. Gras, V. Hernandis and J. Mora, J. Anal. At. Spectrom 17, 142 (2002).

11. G. F. Kirkbright, A.F. Ward and T.S. West, Anal. Chim. Acta 62, 241 (1972). 
TABLE XI

Analyses of $\mathrm{Ca}, \mathrm{Co}, \mathrm{In}, \mathrm{Pb}$, and T1 Using Synthetic Samples Prepared From Commercially Available Standard Reference Materials

\begin{tabular}{|c|c|c|c|c|c|c|c|}
\hline \multirow[b]{2}{*}{ Elements } & \multirow[b]{2}{*}{$\begin{array}{l}\text { Analytical } \\
\text { Lines }\end{array}$} & \multicolumn{3}{|c|}{ S5 } & \multicolumn{3}{|c|}{ s6 } \\
\hline & & $\begin{array}{l}\text { Actual } \\
\text { Concen- } \\
\text { tration } \\
\\
(\mathrm{mg} / \mathrm{L})\end{array}$ & $\begin{array}{c}\text { Amount } \\
\text { Estimated Before } \\
\text { Incorporating } \\
\text { Correction } \\
\text { Factor } \\
(\mathrm{mg} / \mathrm{L})\end{array}$ & $\begin{array}{c}\text { Amount } \\
\text { Estimated After } \\
\text { Incorporating } \\
\text { Correcton } \\
\text { Factor } \\
(\mathrm{mg} / \mathrm{L})\end{array}$ & $\begin{array}{l}\text { Actual } \\
\text { Concen- } \\
\text { tration } \\
(\mathrm{mg} / \mathrm{L})\end{array}$ & $\begin{array}{c}\text { Amount } \\
\text { Estimated Before } \\
\text { Incorporating } \\
\text { Correction } \\
\text { Factor } \\
(\mathrm{mg} / \mathrm{L})\end{array}$ & $\begin{array}{c}\text { Amount } \\
\text { Estimated After } \\
\text { Incorporating } \\
\text { Correction } \\
\text { Factor } \\
(\mathrm{mg} / \mathrm{L})\end{array}$ \\
\hline \multirow[t]{2}{*}{$\mathrm{Ca}$} & 393.366 & 0.2 & $0.50 \pm 0.02$ & 0.21 & 2 & $2.32 \pm 0.06$ & 2.03 \\
\hline & 422.673 & 0.2 & $0.35 \pm 0.02$ & 0.19 & 2 & $2.19 \pm 0.08$ & 2.03 \\
\hline \multirow[t]{2}{*}{$\mathrm{Co}$} & 237.862 & 0.2 & $0.30 \pm 0.02$ & 0.20 & 2 & $2.01 \pm 0.05$ & 1.91 \\
\hline & 238.892 & 0.2 & $0.50 \pm 0.03$ & 0.19 & 2 & $2.37 \pm 0.04$ & 2.06 \\
\hline In & 325.609 & 0.2 & $0.40 \pm 0.02$ & 0.21 & 2 & $2.02 \pm 0.07$ & 1.83 \\
\hline $\mathrm{Pb}$ & 283.305 & 0.2 & $0.42 \pm 0.03$ & 0.17 & 2 & $2.02 \pm 0.06$ & 1.77 \\
\hline $\mathrm{Tl}$ & 190.864 & 0.2 & $0.31 \pm 0.02$ & 0.19 & 2 & $2.19 \pm 0.04$ & 2.07 \\
\hline
\end{tabular}

TABLE XII

Comparison Of the Present Methodology with Existing Analytical Techniques For Common Analytes

\begin{tabular}{|c|c|c|c|c|c|c|c|}
\hline $\begin{array}{l}\text { Ele- } \\
\text { ments }\end{array}$ & $\begin{array}{c}\text { Analytical } \\
\text { Lines } \\
(\mathrm{nm})\end{array}$ & $\begin{array}{c}\text { Estimated by } \\
\text { Present } \\
\text { Method } \\
(\mathrm{mg} / \mathrm{L})\end{array}$ & $\begin{array}{c}\text { Comparison } \\
\text { With Other } \\
\text { Method } \\
(\mathrm{mg} / \mathrm{L})\end{array}$ & $\begin{array}{l}\text { Ele- } \\
\text { ments }\end{array}$ & $\begin{array}{c}\text { Analytical } \\
\text { Lines } \\
\text { (nm) }\end{array}$ & $\begin{array}{c}\text { Estimated by } \\
\text { Present } \\
\text { Method } \\
(\mathrm{mg} / \mathrm{L})\end{array}$ & $\begin{array}{l}\text { Comparison } \\
\text { With Other } \\
\text { Method } \\
(\mathrm{mg} / \mathrm{L})\end{array}$ \\
\hline $\mathrm{Ag}$ & $\begin{array}{l}328.068 \\
338.289\end{array}$ & $\begin{array}{l}0.30 \pm 0.03 \\
0.31 \pm 0.02\end{array}$ & $\begin{array}{l}0.27 \pm 0.04^{*} \\
0.34 \pm 0.02^{*}\end{array}$ & $\mathrm{Mn}$ & $\begin{array}{l}257.611 \\
259.373\end{array}$ & $\begin{array}{l}0.31 \pm 0.03 \\
0.32 \pm 0.02\end{array}$ & $\begin{array}{l}0.33 \pm 0.06^{* *} \\
0.33 \pm 0.05^{* *}\end{array}$ \\
\hline $\mathrm{Al}$ & $\begin{array}{l}396.152 \\
394.401\end{array}$ & $\begin{array}{l}0.28 \pm 0.04 \\
0.30 \pm 0.02\end{array}$ & $\begin{array}{l}0.29 \pm 0.06^{* *} \\
0.33 \pm 0.04^{* *}\end{array}$ & $\mathrm{Na}$ & $\begin{array}{l}588.995 \\
589.592\end{array}$ & $\begin{array}{l}0.33 \pm 0.02 \\
0.30 \pm 0.03\end{array}$ & $\begin{array}{l}0.26 \pm 0.04^{* *} \\
0.27 \pm 0.05^{* *}\end{array}$ \\
\hline B & $\begin{array}{l}208.959 \\
249.677\end{array}$ & $\begin{array}{l}0.29 \pm 0.03 \\
0.28 \pm 0.02\end{array}$ & $\begin{array}{l}0.28 \pm 0.05^{* *} \\
0.28 \pm 0.04^{* *}\end{array}$ & $\mathrm{Ni}$ & $\begin{array}{l}221.648 \\
300.249\end{array}$ & $\begin{array}{l}0.28 \pm 0.03 \\
0.29 \pm 0.02\end{array}$ & $\begin{array}{l}0.31 \pm 0.04^{* *} \\
0.32 \pm 0.04^{* *}\end{array}$ \\
\hline $\mathrm{Ba}$ & 455.404 & $0.31 \pm 0.03$ & $0.32 \pm 0.06^{* *}$ & & 341.476 & $0.28 \pm 0.03$ & $0.33 \pm 0.04^{* *}$ \\
\hline $\begin{array}{l}\mathrm{Bi} \\
\mathrm{Cd}\end{array}$ & $\begin{array}{l}306.772 \\
214.438 \\
226.502\end{array}$ & $\begin{array}{l}0.30 \pm 0.02 \\
0.28 \pm 0.03 \\
0.32 \pm 0.04\end{array}$ & $\begin{array}{l}0.27 \pm 0.04^{* *} \\
0.29 \pm 0.05^{* *} \\
0.33 \pm 0.06^{* *}\end{array}$ & $\mathrm{Sr}$ & $\begin{array}{l}407.771 \\
421.552 \\
460.733\end{array}$ & $\begin{array}{l}0.27 \pm 0.03 \\
0.30 \pm 0.02 \\
0.31 \pm 0.03\end{array}$ & $\begin{array}{l}0.32 \pm 0.05^{* *} \\
0.28 \pm 0.05^{* *} \\
0.27 \pm 0.04^{* *}\end{array}$ \\
\hline $\begin{array}{l}\mathrm{Cr} \\
\mathrm{Cu}\end{array}$ & $\begin{array}{l}205.618 \\
327.396\end{array}$ & $\begin{array}{l}0.30 \pm 0.01 \\
0.33 \pm 0.03\end{array}$ & $\begin{array}{l}0.32 \pm 0.05^{* *} \\
0.27 \pm 0.04^{* *}\end{array}$ & $\mathrm{Zn}$ & $\begin{array}{l}202.613 \\
213.856\end{array}$ & $\begin{array}{l}0.32 \pm 0.02 \\
0.30 \pm 0.01\end{array}$ & $\begin{array}{l}0.28 \pm 0.05^{* *} \\
0.29 \pm 0.04^{* *}\end{array}$ \\
\hline $\mathrm{Fe}$ & $\begin{array}{l}373.486 \\
275.573\end{array}$ & $\begin{array}{l}0.29 \pm 0.03 \\
0.27 \pm 0.02\end{array}$ & $\begin{array}{l}0.28 \pm 0.05^{* *} \\
0.31 \pm 0.05^{* *}\end{array}$ & $\mathrm{Ca}$ & $\begin{array}{l}393.366 \\
422.673\end{array}$ & $\begin{array}{l}1.51 \pm 0.03 \\
1.48 \pm 0.02\end{array}$ & $\begin{array}{l}1.60 \pm 0.08^{* *} \\
1.43 \pm 0.08^{* * *}\end{array}$ \\
\hline $\mathrm{Ga}$ & 417.206 & $0.30 \pm 0.02$ & $0.26 \pm 0.04^{* *}$ & Co & $\begin{array}{l}237.862 \\
238.892\end{array}$ & $\begin{array}{l}1.49 \pm 0.03 \\
1.50 \pm 0.04\end{array}$ & $\begin{array}{l}1.47 \pm 0.07^{* *} \\
1.48 \pm 0.06^{* *}\end{array}$ \\
\hline $\mathrm{Li}$ & 670.78 & $0.28 \pm 0.03$ & $0.27 \pm 0.05^{* *}$ & In & 325.609 & $1.46 \pm 0.07$ & $1.52 \pm 0.07^{* *}$ \\
\hline $\mathrm{Mg}$ & $\begin{array}{l}279.553 \\
280.27 \\
285213\end{array}$ & $\begin{array}{l}0.30 \pm 0.04 \\
0.30 \pm 0.03 \\
030+0.02\end{array}$ & $\begin{array}{l}0.28 \pm 0.04^{* *} \\
0.33 \pm 0.04^{* *} \\
0.30+0.05^{* *}\end{array}$ & $\mathrm{~Pb}$ & $\begin{array}{r}283.305 \\
190.864\end{array}$ & $\begin{array}{c}1.53 \pm 0.06 \\
1.45 \pm 0.07\end{array}$ & $\begin{array}{c}1.59 \pm 0.08^{* *} \\
1.50 \pm 0.07^{* *}\end{array}$ \\
\hline
\end{tabular}

* = Analysis was done in atomioc absorption spectrometry.

** = Analysis was done by D.C. arc atmic emission spectrometry, matrix: $1000 \mathrm{mg} / \mathrm{L} \mathrm{Lu}$. 
TABLE XIII

Comparison of Present Method With Existing Analytical Technique For the Rare Earth Elements

\begin{tabular}{cccc}
\hline Elements & $\begin{array}{c}\text { Analytical } \\
\text { Lines } \\
(\mathrm{nm})\end{array}$ & $\begin{array}{c}\text { Estimated by } \\
\text { Present Method } \\
(\mathrm{mg} / \mathrm{L})\end{array}$ & $\begin{array}{c}\text { Comparison With } \\
\text { Other Method } \\
(\mathrm{mg} / \mathrm{L})\end{array}$ \\
\hline $\mathrm{Ce}$ & 413.380 & $0.53 \pm 0.04$ & $0.52 \pm 0.04 \#$ \\
$\mathrm{La}$ & 418.660 & $0.47 \pm 0.03$ & $0.51 \pm 0.03 \#$ \\
& 408.672 & $0.52 \pm 0.04$ & $0.49 \pm 0.04 \#$ \\
& 333.749 & $0.48 \pm 0.04$ & $0.47 \pm 0.04 \#$ \\
$\mathrm{Gd}$ & 379.478 & $0.49 \pm 0.03$ & $0.51 \pm 0.03 \#$ \\
& 342.247 & $0.50 \pm 0.03$ & $0.52 \pm 0.04 \#$ \\
& 335.047 & $0.51 \pm 0.04$ & $0.48 \pm 0.04 \#$ \\
$\mathrm{Nd}$ & 336.223 & $0.53 \pm 0.02$ & $0.53 \pm 0.02 \#$ \\
& 335.862 & $0.50 \pm 0.04$ & $0.53 \pm 0.04 \#$ \\
$\mathrm{Pr}$ & 430.358 & $0.49 \pm 0.04$ & $0.51 \pm 0.04 \#$ \\
& 406.109 & $0.47 \pm 0.02$ & $0.50 \pm 0.02 \#$ \\
$\mathrm{Dy}$ & 417.731 & $0.50 \pm 0.04$ & $0.47 \pm 0.03 \#$ \\
& 417.939 & $0.52 \pm 0.02$ & $0.47 \pm 0.04 \#$ \\
& 422.535 & $0.46 \pm 0.04$ & $0.51 \pm 0.04 \#$ \\
& 353.17 & $0.50 \pm 0.03$ & $0.48 \pm 0.04 \#$ \\
& 394.468 & $0.49 \pm 0.04$ & $0.49 \pm 0.03 \#$ \\
& 340.78 & $0.52 \pm 0.03$ & $0.49 \pm 0.04 \#$ \\
& 364.54 & $0.52 \pm 0.04$ & $0.50 \pm 0.04 \#$
\end{tabular}

\# = Analysis was done by ion chromatographic technique, Matrix: $1000 \mathrm{mg} / \mathrm{L} \mathrm{Lu}$.

12. M. H. Abdallah, J.M. Mermet and C. Trassy, Anal. Chim. Acta 87, 329 (1976).

13. R. K. Winge,V. A. Fassel, R. N. Kniseley, E. D. Kalb and W. K. Haas, Spectrochim. Acta 32B, 327 (1977).

14. P.W.J.M. Boumans, Spectrochim Acta 438(2), 173 (1988).

15. P. W. J. M. Boumans and M. Bosvuo, Spectrochim. Acta 34B, 59 (1979).

16. N. R. Mcquaker, P. D. Kluckner and G. N. Chang, Anal. Chem. 51, 888 (1979).

17. M. A. Fernandez and G. J. Bastiaans, Anal. Chem. 51, 1402 (1979).

18. G. Wonsch, Talanta, 26291 (1979).

19. R. D. Ediger, ICP Application Study No. 5, PerkinElmer, Inc., Shelton, CT, USA (1979).

20. J. M. Mermet, E. Pehlivanian and J. Robin, Proc. Int. Winter Conference I980 on Developments in Atomic Plasma Spectrochemical Analyses, Heyden, London, UK (1980).

21. G. F. Kirkbright and H. M. Tinsley, Talanta 26, 41 (1979).
22. R. H. Scott, A. Strasheim and M. L. Kokot, Anal. Chim. Acta 82, 67 (1976)

23. G. F. Larson and V. A. Fassel, Appl. Spectrosc. 33, 592 (1979).

24. G. F. Larson, V. A. Fassel, R. K. Winge and R. N. Kniseley, Appl. Spectrosc. 30, 384 (1976).

25. V. A. Fassel, J. M. Katzenberg and R. K. Winge, Appl. Spcctrosc. 33, 1 (1979).

26. V.C. Adya, A. Sengupta and S.V. Godbole, Atomic Spectroscopy 35(1), 25 (2014).

27. A. Sengupta, V.C.Adya, T. K. Seshagiri, and S.V. Godbole, At. Spectrosc. 34(2), 53 (2013).

28. A. Sengupta and V.C. Adya, At. Spectrosc. 34(6), 207 (2013).

29. A. Sengupta, S.K. Thulasidas and V. Natarajan, At. Spectrosc. 35 6), 247 (2014).

30. Y. Wei, R. L. Brainard, Advanced Processes for 193-NM Immersion Lithography, ISBN 0-8194-7557-2 (2009).
31. J. W. Nielsen, S. L. Blank, D. H. Smith, G. P. Vella-Coleiro, F. B. Hagedorn, R. L. Barns and W. A. Biolsi, J. Electronic Materials 3(3), 693 (1974).

32. D. Daghighian, F. Shenderov, $P$. Pentlow, K.S. Graham, M.C. Eshaghian, B. Melcher, and C.L. Schweitzer, Nuclear Science 40(4), 1045 (1993).

33. M. Gargaud, H. Martin, and P. Claeys, Lectures in Astrobiology, ISBN 3-540-33692-3 Springer, p. 51 (2007).

34. H. Sigel, Metal complexes in tumor diagnosis and as anticancer agents. CRC Press. p. 98, ISBN 0-8247-5494-8 (2004).

35. N.K. Porwal, A.A. Argekar, P.J. Purohit, A.G. Page and M.D. Sastry, Fresenius J. Anal. Chem. 338, 255 (1990).

36. A.G. Page, K.H. Madraswala, S.V. Godbole, M.J. Kulkarni, V.S. Mallapurkar and B.D. Joshi, Fresenius Z. Anal. Chem. 315, 38 (1983).

37. A.G. Page, S.V. Godbole, S. Deshkar, Y. Babu and B.D. Joshi, Fresenius J. Anal. Chem. 287, 304 (1977).

38. A.G.I. Dalvi, C.S. Deodhar, T.K. Seshagiri, M.S. Khalap and B.D. Joshi, Talanta 25, 665 (1978).

39. B. Rajeswari, B.A. Dhawale, T.R. Bangia, J.N. Mathur and A.G. Page, J. Radioanal. Nucl. Chem. 254 (3), 479 (2002).

40. A.Sengupta, M. J.Kulkarni and S. V. Godbole, J. Radioanal. Nucl. Chem. 289(3), 961 (2011).

41. A.A. Argekar, M.J. Kulkarni, J.N. Mathur and A.G. Page, Talanta 56(4), 591 (2002).

42. C. Mahan, S. Bonchin, D. Figg, D. Gcrth and C. Collier, J. Anal. Atom. Spectrum. 15 (8), 929 (2000).

43. S. Marin, S. Cornejo, C. Jara and N. Duran, Fresenius' J. Anal. Chem. 355 (5-6), 680 (1996).

44. E.A. Huff, At. Spectrosc??. 42 (1-2), 275 (1987).

45. N. Pathak, V.C. Adya, S.K. Thulasidas, A. Sengupta, T.K. Seshagiri and S.V. Godbole, Atomic Spectroscopy 35(1), 17 (2014).

46. T. Blazheva and A. Delijska - Krushevska, Fresenius J. Anal. Chem. 338, 294 (1990).

47. M.C. Bruzzoniti, E. Mentasti, C. Sarzanini, M. Braglia, G.Cocito and J. Kraus, Anal. Chim. Acta 332, 49 (1996). 